Koh, N., Hahn, T., Ituarte-Lima, C. Safeguards for Enhancing Ecological Compensation in Sweden, Land Use Policy, 64: 186-199

Note: This is the authors' accepted manuscript; the final version of the paper including copyediting can be accessed at http://dx.doi.org/10.1016/j.landusepol.2017.02.035

\title{
Safeguards for Enhancing Ecological Compensation in Sweden
}

ABSTRACT Ecological compensation (EC) is being explored as a policy instrument for the European Union's 'No Net Loss of Biodiversity and Ecosystem Services' initiative. EC is commonly associated with the Polluter-Pays Principle, but we propose the Developer-Pays Principle as a more appropriate principle. Safeguards that are relevant to local and national contexts are needed when addressing social-ecological resilience in the face of risks associated with EC. The operationalisation of EC in Sweden is assessed through two case studies, the E12 highway and Mertainen mine. The institutional design and implementation procedures are investigated through semi-structured interviews as well as an analysis of legal and other written documents. Using a multi-level governance framework, we examine four key disputed issues within compensation. Our results suggest that (i) Risk of a licenseto-trash can be minimised; (ii) Complementary quantitative and qualitative ecological valuation methods are needed to achieve additionality and No Net Loss; (iii) Compensation pools may be a promising strategy to secure land availability; and (iv) Social safeguards are vital for EC in highincome countries as well, where they are currently understudied. We conclude that EC cannot be the main instrument for nature conservation, but rather complementary to a strong legal framework that protects biodiversity and ecosystems in addition to the sustained and equitable benefits of ecosystem services.

KEY WORDS: Biodiversity safeguards, social safeguards, mitigation hierarchy, social-ecological systems, biodiversity leakage, Convention on Biological Diversity.

\section{Highlights:}

1. Two case studies reveal ecological compensation (EC) in practice in Sweden.

2. Compensation legislation must apply to roads and urbanisation to achieve No Net Loss.

3. EC in Sweden is ad hoc; no standards for quantitative and qualitative valuation.

4. Compensation pools may be a promising strategy to secure land availability.

5. Social safeguards and equity are important aspects of EC but have been understudied.

\section{Introduction}

Within the European Union (EU), 86,000 hectares of green areas are converted to developments annually (Conway et al., 2013). This has prompted the 'No Net Loss (NNL) of Biodiversity and Ecosystem Services' policy, where ecological compensation is one of the policy instruments considered (European Commission, 2014). Legislation for ecological compensation is clearly defined in the EU for Natura 2000 areas; however, outside these protected areas the compensation legislation is ambiguous and varies substantially between Member States (eftec et al., 2010a).

Ecological compensation is understood as 'the substitution of ecological functions or qualities that are impaired by development' (Cuperus et al., 1999). It includes an array of approaches, with varying degrees of 'market' involvement (Hahn et al., 2015). We use the term 'ecological compensation' (EC) rather than 'biodiversity offsets,' as the former is regarded as a broader term encompassing a range of measures to recompense (Conway et al., 2013). The 
rationale of this instrument is not only to compensate for ecological losses but also to slow down development on the most valuable green areas, as such projects would be more costly to compensate. Hence, NNL and EC are strategies to halt biodiversity loss while still allowing a dynamic economic development.

Existing EC policies globally result in approximately 187,000 ha of land placed under some form of conservation protection each year (Madsen et al., 2011). The Convention on Biological Diversity (CBD) has also noted EC as a Biodiversity Financing Mechanism (BFM) ${ }^{i}$ and this has caused some controversy (Schultz et al., in review). In order to account for the social and biodiversity opportunities and risks associated with BFMs, the CBD Secretariat developed voluntary guidelines for safeguards based on a stakeholder dialogue process. Safeguards refer to 'measures for maximising the protection of biodiversity and people's livelihoods while minimising negative impacts' (Ituarte-Lima et al., 2014). These guidelines were adopted in 2014 by the $12^{\text {th }}$ Conference of the Parties (see Box A.1 in Appendix A), which also urged Parties to consider undertaking a review and assessment of existing legislation and policies governing BFMs.

The idea of compensation and offsets involves commodification (Hahn et al., 2015) and value clashes (Sullivan \& Hannis, 2015); many programs have been criticized for being unsuccessful in meeting their ecological goals whilst posing additional social risks (Brown \& Veneman, 2001; Gibbons \& Lindenmayer, 2007; Curran et al., 2014). Despite these risks, EC is presently being developed in several countries, including Sweden. Swedish courts are increasingly employing existing legal provisions that allow for attaching a compensation requirement to the permission. However, the laws are ambiguous and compensation projects are therefore conducted in an ad hoc manner without explicitly requiring the achievement of NNL (eftec et al., 2010a, p. 209).

The purpose of this paper is to analyse four key disputed issues that we believe are crucial for operationalising EC in Sweden: (i) Avoiding a 'license-to-trash', (ii) Availability of compensation land, (iii) Ecological loss-gain methods and (iv) Social safeguards. The first two issues concern the mitigation hierarchy and together with the third issue, they address the biodiversity safeguards. Social issues concern the whole operationalisation of EC, including substantive (e.g. access/tenure rights) and procedural (e.g. participation) safeguards. These four issues have been highlighted as unique and controversial features of EC policy design (Ruhl \& Salzman, 2006; McKenney \& Kiesecker, 2010; Quétier \& Lavorel, 2011; Bull et al., 2012; Gardner et al., 2013). In this paper, we have chosen two case studies with varying degrees of socioecological complexity and consequences for distinct groups of people to assess both biodiversity and social safeguards. We use a multilevel governance framework of principles and safeguards to examine the operationalisation of EC in the selected case studies.

\section{Theoretical framework and methods}

\subsection{Multilevel governance, principles and safeguards}

International principles, CBD guidelines and general national legislation are key elements of multilevel governance and can be used for framing safeguards in BFMs and ensuring consistency with the CBD and other international obligations (Ituarte-Lima et al., 2014). Box 1 in Appendix A outlines the CBD Guidelines relevant to this study.

The equity principle (Sands \& Peel, 2012) is manifested in the third objective of the CBD: 'the fair and equitable sharing of the benefits arising out of the utilisation of genetic resources.' This is enshrined in various international environmental agreements and national legislation. This principle allows considerations of justice and fairness in the establishment, operation and application of environmental policy instruments. Hence, when the CBD promotes EC and other BFMs, they call for a broader governance approach to valuation and financing that does not 
'undermine achievement of the Convention's three objectives' (Convention on Biological Diversity (CBD), 2011).

Although social equity also applies to high-income countries, it is not analysed in the same manner as biodiversity-related challenges (eftec et al., 2010b; Conway et al., 2013; Tucker et al., 2013). In an attempt to overcome this bias, we emphasise equity by considering the distributive equity dimensions of the equity principle and its link to the definition of ecosystem services (McDermott et al., 2013). When assessing the equity principle in relation to 'NNL of ecosystem services', there is a need to disaggregate the broad definition of ecosystem services as 'the benefits people derive from ecosystems' (Millennium Ecosystem Assessment, 2005) into specific benefits derived by different sections of society (Daw et al., 2011). This includes those in relatively disadvantaged positions or with differentiated individual and collective rights. The UN special rapporteur on human rights and environment highlights that more research is necessary to understand the differentiated effects of the loss and degradation of biodiversity in different sectors of society, especially the effects on people in vulnerable situations (Knox, 2017).

\subsection{Developer-Pays principle and the mitigation hierarchy}

The mitigation hierarchy requires developers to avoid, minimise and restore biodiversity impacts before resorting to compensation off-site (Business and Biodiversity Offsets Programme (BBOP), 2009). This hierarchy is widely endorsed as an operationalisation of EC (Conway et al., 2013; Tucker et al., 2013). Environmental Impact Assessments (EIAs) may provide information for the different steps of the hierarchy, but EIAs do not generally address compensation (see Table 1). The Polluter-Pays Principle (PPP) is often used as a principle to justify EC (Jenkins et al., 2004; Wende et al., 2005; Tucker et al., 2013). PPP allocates responsibility to the polluter to bear the expenses of ensuring prevention and control measures for a rational use of natural resources. In this original understanding of PPP, measures for reducing (controlling) pollution should be paid for by the polluter, as motivated by international competitiveness (OECD, 1972). An extended version of the PPP obliges the polluter to pay for remaining damage after minimising pollution, e.g. a pollution tax. However, even with this extended PPP, polluters only pay monetary compensation; there is usually no link to restoration. PPP is therefore inadequate as a principle for describing EC, for which biophysical (non-monetary) compensation is crucial.

We conclude from this theoretical analysis that EC (and biodiversity offsets) are based on two principles: (i) the equity principle and (ii) a new principle that we call the "Developer-Pays Principle" (DPP). So far, the few references to DPP in the scientific literature do not relate to EC or biodiversity offsets but mainly archaeological research (e.g. Willems, 2007; Ciuchini, 2010). We propose that for EC, the DPP entails an obligation of the developer to ensure a) identification and legal approval of a suitable location for development; b) minimisation of damage on ecosystems; c) post-impact restoration of ecosystems; and d) off-site compensation of the ecosystem functions and services that could not be restored on-site. Table 1 suggests how the DPP fully captures the entire mitigation hierarchy sequence.

\section{Table 1}

A comparison of the Developer-Pays Principle, Polluter-Pays Principle and Environmental Impact Assessment as different principles and tools to operationalise EC.

\begin{tabular}{|l|l|l|l|}
\hline $\begin{array}{l}\text { EC (Mitigation } \\
\text { hierarchy) }\end{array}$ & $\begin{array}{l}\text { Developer-Pays } \\
\text { Principle (DPP) }\end{array}$ & $\begin{array}{l}\text { Polluter-Pays } \\
\text { Principle (PPP) }\end{array}$ & $\begin{array}{l}\text { Environmental } \\
\text { Impact Assessment }\end{array}$ \\
\hline Avoidance & Approval of location & N/A & $\begin{array}{l}\text { Assessing alternative } \\
\text { locations }\end{array}$ \\
\hline Minimising impacts & $\begin{array}{l}\text { Minimising damage to } \\
\text { ecosystems }\end{array}$ & Controlling pollution & $\begin{array}{l}\text { Assessing measures to } \\
\text { reduce impacts }\end{array}$ \\
\hline On-site restoration & $\begin{array}{l}\text { Post-impact } \\
\text { restoration }\end{array}$ & N/A & $\begin{array}{l}\text { Assessing post-impact } \\
\text { restoration }\end{array}$ \\
\hline
\end{tabular}




\begin{tabular}{|l|l|l|l|}
\hline $\begin{array}{l}\text { Off-site } \\
\text { compensation for } \\
\text { residual impacts }\end{array}$ & $\begin{array}{l}\text { Compensation of } \\
\text { ecosystem functions } \\
\text { (non-monetary) }\end{array}$ & $\begin{array}{l}\text { Extended PPP: } \\
\text { monetary compensation } \\
\text { for damage }\end{array}$ & N/A \\
\hline
\end{tabular}

This paper analyses the extent to which the mitigation hierarchy is applied as a biodiversity safeguard. The first step, Avoidance, should ensure that alternative sites are considered and the ones incurring unacceptable damage to biodiversity and ecosystem services are avoided ("no-go areas"). Moreover, if the existence of a compensation project renders authorities to approve a development that they would not have approved otherwise, compensation programs risk becoming a 'license-to-trash' (McKenney \& Kiesecker, 2010). This risk is substantial, with evidence suggesting that this has already happened in Sweden (Schultz et al., 2013, p. 96; Lerman, 2014, p. 75). It is unlikely that a conservation program that increases the initial degradation of biodiversity and ecosystem services would be a credible strategy to achieving NNL. This would be similar to replacing legal standards for pollution control with low taxes that would result in an increase of overall pollution, and subsequently using the revenues to compensate for the damage. There is broad consensus among EC practitioners (Business and Biodiversity Offsets Programme, 2009; eftec et al., 2010a) as well as in the scientific literature (Hough \& Robertson, 2009; Burgin, 2010; Clare et al., 2011) that the license-to-trash must be controlled by strong regulations if it is to become an effective instrument for biodiversity conservation. The Swedish Environmental Protection Agency (SEPA) also emphasises that the compensation instrument must not influence the approval decision (SEPA, 2016, p. 43)

The last step of compensation requires a supply of potential land areas to choose from, an issue that was suggested to be an obstacle in Sweden (Schultz et al., 2013, p. 100; Persson, 2014, p. 4). Our two case studies will analyse whether this issue had hindered the EC process and if so, identify possible remedies. The allocation of development and compensation areas also has consequences for the wellbeing of local communities, which justifies social safeguards to ensure equity.

\subsection{Transaction costs in operationalising EC}

Operationalising EC, including the above-mentioned principles and safeguards, involves the consideration of transaction costs in an efficient way. Transaction costs are associated with the negotiation of an economic exchange and can be summarised as costs for information, contracting and enforcement (Bromley, 1991). Compensation measures in Sweden are currently determined ad hoc, usually through the best professional judgement from various authorities and environmental consultants (eftec et al., 2010b, p. 88). This leads to inflated transaction costs as the lack of an established best practice entails inconsistent approaches to valuing losses and gains. In other countries, authorities have set rules for conducting biodiversity equivalence, usually in terms of ecological functions (e.g. Germany) or habitat types (e.g. Australia) (Koh et al., 2014).

Compensation pools and habitat banking could be a means of assisting the mitigation hierarchy by increasing land availability and reducing transaction costs. However, Briggs et al. (2009, p. 117) warn that "[w]ithout careful regulation, habitat banks could offer low-cost compensation as a result of cutting corners on conservation, and the market would reward poorly managed banks and thus harm conservation efforts". Since ecosystem values are complex and information asymmetries are substantial, seeking low transaction costs is likely to result in poor performance of EC programs (Kihslinger, 2008). Recent literature (Glicksman \& Kaime, 2013; Hahn et al., 2015) increasingly recognises that economic instruments for ecosystem services may require more, not less, regulation to achieve environmental benefits and address associated risks. The dichotomy of government regulation versus market is false (Vatn, 2015) and this is particularly obvious for EC since successful outcomes seem to be a function of a comprehensive 
regulation (eftec et al., 2010b, p. 237). Much of the ecosystem values are a public good, and it is widely known in economic theory that markets are not well suited to govern public goods for efficient and equitable outcomes (Gómez-Baggethun \& Muradian, 2015; Vatn, 2015).

\subsection{Methods}

A case study method (Fidel, 1984; Yin, 1994) was employed by selecting two compensation cases that were legally required by Chapter $16 \S 9$ of the Swedish Environmental Code. The first case, the Mertainen mine, has direct impacts on 1,220 ha of mostly old-growth forests and is a well-known case in Sweden with substantial protocols from courts. It also involves the infringement on reindeer herding of two indigenous Sami communities. The second case is an extension of the E12 highway with direct impacts on 6.3 ha of relatively less complex ecological and social values. These contrasting cases were chosen to shed light on how differing levels of complexity may influence the operationalisation of EC.

Written data comprising of court documents, EIAs and land-use plans were collected. Semi-structured interviews were carried out with 19 key informants including authorities from the Country Administrative Boardii (CAB) [Länsstyrelsen], the Land and Environmental Courtiii (LEC) [Mark- och Miljödomstolen], municipalities, developers, environmental consultants, landowners, indigenous peoples and local communities (see Appendix B for informant list). Specific interview guides with open-ended questions (Kvale \& Brinkmann, 2009) were prepared for each interview, focused upon the four key disputed compensation issues. Interviews were mostly conducted face-to-face, with some by telephone, and each lasted approximately 30-90 minutes. The interviews were recorded and partially transcribed.

\section{Current state of EC in Sweden and the case studies}

\subsection{Legal framework for EC beyond natural protected areas}

EC is required in Sweden for development within Natura 2000 sites and other protected areas, based on Chapter 7 of the Environmental Code. These are usually ad hoc compensation projects targeting specific biodiversity values (Hägglund \& Enetjärn, 2014, p. 9). Outside of natural protected areas, in the 'everyday landscape', there is yet to be a national policy to explicitly regulate EC and achieve NNL. Nevertheless, there are existing legal provisions of a general nature that allows for compensation (see Table 2).

Table 2

Excerpt of Swedish laws associated with EC requirements. ${ }^{\text {iv }}$

\begin{tabular}{|l|l|l|}
\hline Law & Compensation for infringements & Applicability \\
\hline $\begin{array}{l}\text { Chapter 7, Environmental } \\
\text { Code }\end{array}$ & $\begin{array}{l}\text { On nature reserves, culture reserves, } \\
\text { natural monuments or Natura 2000 } \\
\text { areas }\end{array}$ & Protected areas only \\
\hline $\begin{array}{l}\text { Chapter 16§9, } \\
\text { Environmental Code }\end{array}$ & $\begin{array}{l}\text { In case of 'encroachment on public } \\
\text { interests due to the activity' }\end{array}$ & $\begin{array}{l}\text { Protected areas and } \\
\text { the everyday } \\
\text { landscape }\end{array}$ \\
\hline $\begin{array}{l}\text { Species Protection } \\
\text { Ordinance } \\
\text { [Artskyddsförordning] }\end{array}$ & $\begin{array}{l}\text { In the presence of listed threatened } \\
\text { species under the EU Habitats Directive }\end{array}$ & $\begin{array}{l}\text { Protected and the } \\
\text { everyday landscape }\end{array}$ \\
\hline
\end{tabular}

The paper focuses on the application of Chapter $16 \S 9$ as the wording of "encroachments on public interest" are based in the Swedish Constitution Chapter $2 \S 15$ and permits a broad interpretation of public interest, which could extend beyond biodiversity values. Compensation can be requested on areas with or without formal protection, if there is an intrusion on natural, social or conservation interests. 
According to Chapter 6 of the Swedish Environmental Code, the developer of certain projects is required to conduct an EIA that then serves as a basis for project approval. If the permit is approved, then a second decision occurs where the authority responsible for approving the project (usually the CAB or LEC) examines the EIA's proposed measures for avoidance, minimisation and on-site post-impact restoration. If these measures are deemed insufficient, the authority may require the developer to compensate. ${ }^{v}$ However, for roads and railways, compensation can only be required when intruding on protected areas. This legal exception reflects the power of the Swedish Transport Administration [Trafikverket] that is in charge of the process (Jacobsson, pers. comm.). Similarly, the Plan and Building Act governs the EIA process for housing development and this does not include a legal provision for EC.vi Hence, two major drivers of biodiversity loss: transportation infrastructure and urbanisation, lack legal provisions for EC unless the development occurs in protected areas. Implementing NNL in Sweden therefore requires fundamental legal reform (Lerman \& Hedlund, 2013, p. 28).

Although the Environmental Code has been in effect since 1999, compensation has not been applied largely in the planning system (Rundcrantz \& Skärbäck, 2003; SEPA, 2015). Whereas the three initial steps of the mitigation hierarchy (see Table 1) already belong to established environmental legislation and the EIA (Rundcrantz, 2006), the compensation step represents a new challenge for authorities. A review of all approval decisions based on the Environmental Code submitted to SEPA (2015, p. 23) during 2011- 2014 found that out of 10,000 cases, 1,137 cases had required some sort of EC. Only 150 of those cases had applied Chapter $16 \S 9$. Hence, the opportunity to require compensation for biodiversity loss in the everyday landscape is not often exercised and similar intrusions have resulted in different requirements (SEPA, 2015, p. 25). This has motivated SEPA $(2012 ; 2015 ; 2016)$ to provide further guidance on EC. Nonetheless, there is a growing demand for EC in recent years. Authorities have been increasingly exercising Chapter $16 \S 9$ and the Species Protection Ordinance, while municipalities have also developed their own compensatory guidelines (Schultz et al., 2013, p. 233; Hägglund \& Enetjärn, 2014).

Considering the multi-level governance framework of this paper, the selected case studies of the E12 highway and Mertainen mine bring relevant insights to Swedish national and subnational socio-legal processes as well as to contemporary discussions at the international level on mainstreaming biodiversity within and across sectors. The 2016 UN Biodiversity Conference that took place in Mexico focused on mainstreaming biodiversity for well-being.vii Decision XIII/3, adopted by the Parties of the this Convention -including Sweden-, explicitly recognises that "extractive industries as oil and gas and mining, ... residential construction, have the potential to impact adversely on biodiversity" and "102. Decides that the Conference of the Parties should consider, at its $14^{\text {th }}$ meeting, the mainstreaming of biodiversity into the following sectors: energy and mining; infrastructure; manufacturing and processing industry; and health" (emphasis added). Reference to human rights in this paper provides inputs for mainstreaming biodiversity across sectors, since human rights are of a cross-sectorial nature.

\subsection{Case studies}

\subsubsection{E12 highway, Umeå}

In 2011, the $\mathrm{CAB}$ requested Trafikverket to compensate for the $\mathrm{E} 12$ highway development that infringes on 6.3 ha of a Natura 2000 area (Trafikverket vs. CAB Västerbotten, 2011) (Fig. 1). The impact area is arable land that provides habitat for various bird species, but has otherwise low ecological values (Vägverket, 2003). The development results in bird habitat loss and landscape fragmentation on Natura 2000 area, which would justify the use of Chapter 7 of the Environmental Code. However, only the Swedish government can require compensation according to Chapter $7 \S 28-\S 29$. Due to the relatively small biodiversity losses, the government would probably not take this action (Jacobsson, pers. comm.). The CAB then required compensation according to Chapter 16§9. Compensation measures were proposed on 12 ha of 
agricultural land approximately five $\mathrm{km}$ from the impact site and featured restoration of overgrown land to open pastures. The developer agreed to finance the compensation measures over a 10-year period, in which they contracted a nearby agricultural college for management and monitoring activities.

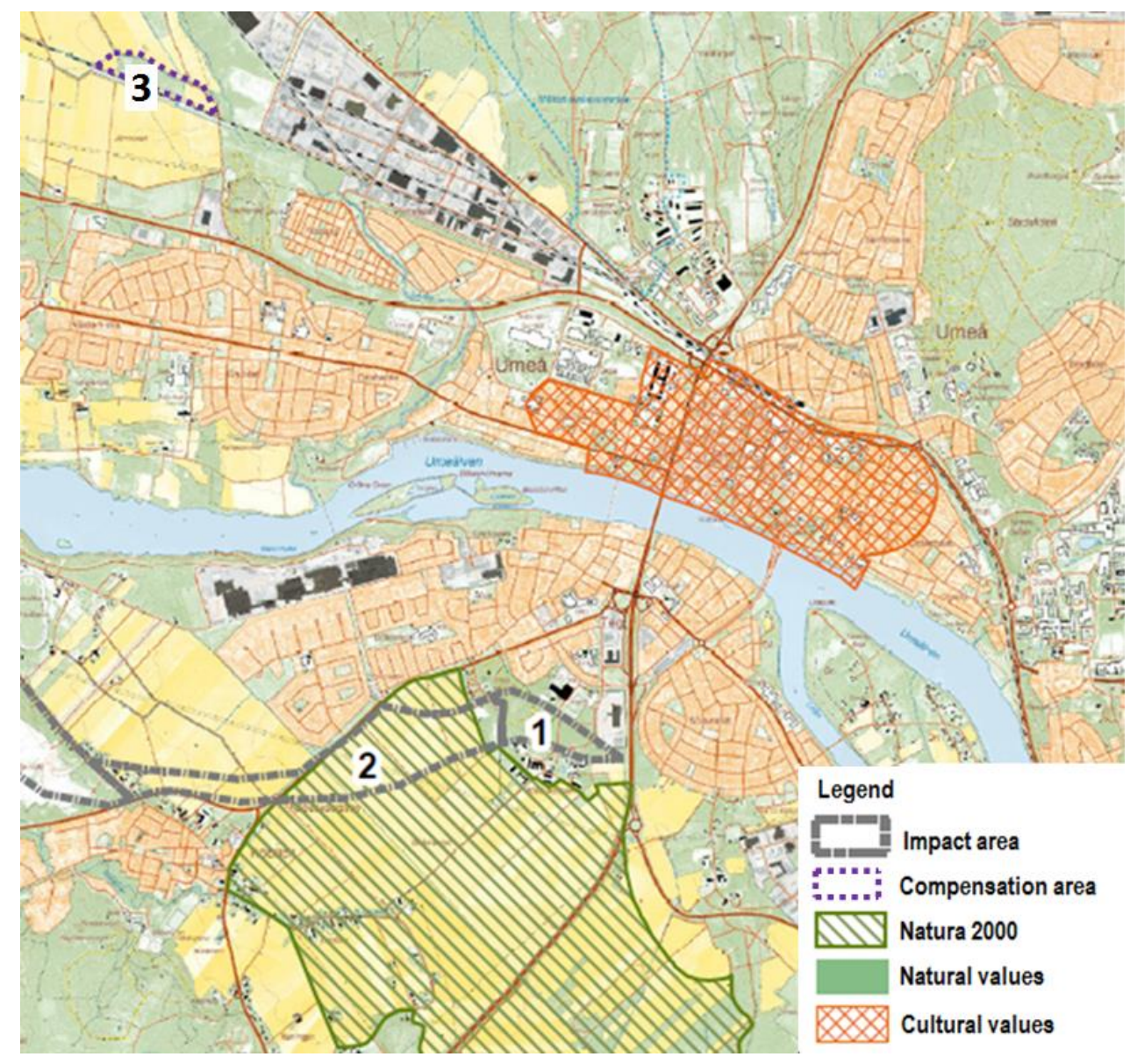

Fig. 1. Location of E12 highway impact site (Area 1 and 2) that intersects a corner of the Natura 2000 area and the compensation site (Area 3). Source: (Enetjärn Natur AB, 2009).

\subsubsection{Mertainen mine, Kiruna}

In December 2013, the LEC approved the final proposal for Mertainen mine by the stateowned mining company LKAB (LKAB vs. CAB Norrbotten et al., 2013a). Against the development was a coalition of interests including the CAB, SEPA, Kiruna municipality and two Sami communities. The impact site consists of 1,220 ha of forest and wetland habitats. It is not a protected area but has high conservation values, containing a number of rare species listed by the Species Protection Ordinance, and is used by the indigenous Sami people for reindeer grazing (Enetjärn Natur AB, 2014a). Areas that are of national interest for reindeer husbandry should be protected "as far as possible" according to Chapter $3 \S 5$ of the Environmental Code. However, areas of national interest for biodiversity and recreation (Chapter 3§6), and for mining (Chapter $3 \S 7)$ are also prioritised for protection. Hence, the Mertainen case demonstrates a clash of four national interests: reindeer husbandry, nature conservation, recreation, and mineral extraction. Other national interests of land use include commercial fishing, industrial and military plans. If an area is of national interest for several incompatible uses, precedence should be given to military plans or uses which "promote a sustainable management of land, water and other aspects of the environment" (Chapter $3 \S 10$ ). Compensation was then required according to Chapter $16 \S 9$ due to "significant harm to high natural values including old-growth conifer forests and red-listed species" (LKAB vs CAB Norrbotten, 2013b, p. 20) 
In September 2014, the LEC approved LKAB's compensation plan for Mertainen (LKAB vs. CAB Norrbotten et al., 2014). LKAB signed an agreement with an institutional landowner, the Jukkasjärvi forest commons, to protect at least an equivalent amount of hectares impacted in Mertainen (Area 1 in Fig. 2) within the maximum area of 2,600 ha at Kuosajänkkä (Area 2 in Fig. 2). The ambition of the compensation project was to achieve 'No Net Loss of biodiversity', with the purpose of developing loss-gain valuations based on the international Business and Biodiversity Offsets Programme (BBOP) standards (Enetjärn Natur AB, 2014a).

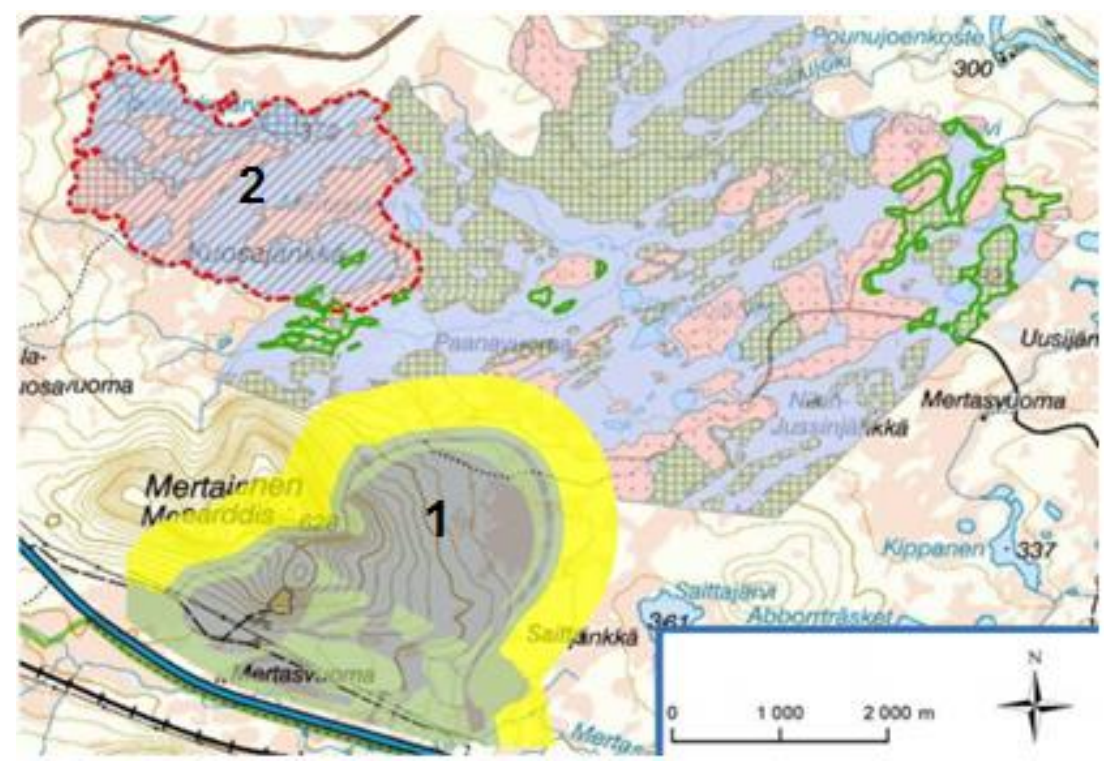

Fig. 2. Location of the impact site Mertainen (1) that is adjacent to the compensation site Kuosajänkkä (2). Source: (Enetjärn Natur AB, 2014a).

\section{Results}

\subsection{The avoidance step}

To reduce the risk of 'license-to-trash', SEPA (2016, p. 8) emphasises that the Avoidance step should be considered in two stages. First, will the proposed development cause unacceptable damage? Second, if it is acceptable, permission is granted and appropriate compensation measures are decided. The second stage must not influence the decision in the first stage. This paper examines Avoidance as to firstly, whether the spatial placements of development (choosing the least damaging of all viable options) were considered in the approval process; and secondly, to what extent compensation influenced the approval process (i.e. contributed to the decision to approve).

In the E12 case, a redirection of the highway was deemed necessary to ease traffic congestion and reduce air pollution in Umeå city centre. Permission for the development was granted, as the $\mathrm{CAB}$ ruled that the development would not affect the conservation priorities of the Natura 2000 area in a significant manner (Trafikverket, 2011). The chosen alternative incurs relatively little intrusion on an area with low ecological values within the Natura 2000 site and the worst alternative location of the E12 extension, West of Lake Prästsjön, was avoided.viii We found no indication of a license-to-trash, as the $\mathrm{CAB}$ distinguished between the legal approval and compensation by noting: 'if the CAB refuses permission, it doesn't help if the company suggests a compensation plan' (Jacobsson, pers. comm.).

Concerning mining, the legal support for the industry is strong in Sweden. Similar to marine fisheries, mining companies are seen as the owners of the natural resource; they pay only $0.2 \%$ of the revenues from mining as resource tax (Mineral Act 7:7). In 2013, the Swedish 
government launched "The Mineral Strategy" with the objective to reinforce Sweden's position as the leading mining country in the EU by increasing international competitiveness and creating more job opportunities in rural areas (Government Offices of Sweden, 2013). In the Mertainen case, this entailed that legal permission was granted despite opposition from several parties. LKAB was then required by the LEC to take mitigation measures to minimise expected adverse effects including lowering of groundwater, habitat destruction, dust emissions, losses for reindeer husbandry as well as air and water pollution.

Different sites with iron ores were considered, with Mertainen found to be the most convenient as it is located nearby LKAB's processing plants in Kiruna and accessible through existing infrastructure. Of the alternate mining site designs with variations in location of rock deposits and processing areas, the chosen alternative had a more concentrated area of mining operations. This resulted in a smaller area of high and highest natural values impacted by the site, in addition to using only one recipient watercourse instead of two (Enetjärn Natur AB, 2014a, p. 19). The chosen alternative had also reduced effects on recreational activities, a more constrained spread of noise, shorter transport routes and lower exhaust emissions (LKAB, 2012, p. 137). Moreover, the compensation plan did not appear to have influenced the LEC's decision to approve the project: 'We cannot give permission to degrade an area in an unacceptable way just because another area will be restored' (Bergström, pers. comm.). This suggests that the requirements of the avoidance step were met.

We conclude that in both cases, the Swedish authorities showed sufficient awareness of the risks related to license-to-trash. ${ }^{\text {ix }}$ This finding has also been supported by Rundcrantz (2006).

\subsection{Identifying and contracting compensation land}

Within these case studies, criteria for compensation land were determined through a negotiation process. Both case studies faced significant challenges, E12 in identifying suitable compensation land and Mertainen in contracting access to land.

In the E12 case, three criteria were involved in selecting a compensation site: (i) land owned by Umeå municipality; (ii) relatively close proximity between sites; and (iii) similar ecological values with the impact site (Grellmann, pers. comm.). The investigation for a location that met all three requirements spanned over a year because not all actors were familiar with the process (Jonsson, pers. comm.). Close collaboration between the developer and municipality resulted in the compensation site being located in a green corridor, complementary to the city's master plan. This reinforced the municipality's capacity for land use planning and green infrastructure development in an innovative manner.

In Mertainen, an easement agreement with Jukkasjärvi forest commons concerning the area Kuosajänkkä $(2,600 \mathrm{ha})$ was found to be an acceptable solution by the LEC, in terms of location and presence of natural values (Enetjärn Natur AB, 2014b; LKAB vs. CAB Norrbotten et al., 2014). The agreement is for 50 years, the maximum period possible under Chapter $7 \S 3$ of the Land Code. The option to make Kuosajänkkä a nature reserve (i.e. protection in perpetuity) was unacceptable to the landowner. Kiruna municipality questioned the easement, as it is unclear what would happen to the site after the 50-year compensation period (LKAB vs. CAB Norrbotten et al., 2014, p. 15).

Nevertheless, the CAB was content with obtaining the maximum legal period possible and they now have the ambition of instating a nature reserve after 50 years; at present they 'need to focus their budget on coastal areas' (Wikström, pers. comm.). There were two main conditions for compensation: similar ecological values and additionality, which was interpreted as an area without any prior formal protection (LKAB vs. CAB Norrbotten et al., 2013a, p. 22). However, the question is whether this interpretation is consistent to NNL. 
SEPA noted that Chapter $16 \S 9$ is not conditional for 'full compensation of environmental values' as there is no legal provision for NNL (LKAB vs. CAB Norrbotten et al., 2014, p. 14). The compensation plan was accepted in September 2014 without any appeal, possibly due to fatigue amongst stakeholders throughout the complicated compensation investigation (Nilsson, pers. comm.). Kuosajänkkä was selected as the landowner is not certified for sustainable forestry by the Forest Stewardship Council and was not previously on the CAB's list of potential nature reserves (Wikström, pers. comm.). Additionality would be attained if Kuosajänkkä's forests would have been harvested in the near future. This assumption, however, cannot be confirmed because the landowner had no immediate plans to harvest. The manager notes, "It is difficult to say what would happen. Most likely, the forest would not be cut within the next ten to twenty years as the price of forest products is currently low" (Johansson, pers. comm.). No harvesting had been conducted over the past two years from the 28,000 ha of productive forests owned by the landowner due to unfavourable market prices.

If low prices continue, the agreement to set aside Kuosajänkkä for 50 years will have no effect on nature conservation. In the event of high prices, the landowner may harvest surrounding areas throughout the next 50 years, before finally harvesting Kuosajänkkä. This highlights a risk of 'biodiversity leakage', where timber harvesting is displaced outside the compensation project's boundaries (Harrison \& Paoli, 2012). Since predicting the price of forest products is an uncertain task, it remains unclear whether the protection of Kuosajänkkä actually results in additionality.

\subsection{Ecological loss-gain methods}

The case studies demonstrate two different approaches to determining losses and gains: qualitative description and quantitative scoring methods (see Table 3).

Table 3

Ecological loss-gain methods and their equivalence approach.

\begin{tabular}{|l|l|l|l|}
\hline Case study & Sum of losses & Sum of gains & $\begin{array}{l}\text { Compensation } \\
\text { approach }\end{array}$ \\
\hline $\begin{array}{l}\text { E12 } \\
\text { highway }\end{array}$ & $\begin{array}{l}\text {-13 ha of direct and } \\
\text { indirect impacts } \\
\text {-Habitat for 19 bird } \\
\text { species }\end{array}$ & $\begin{array}{l}\text {-12 ha of habitat for birds and } \\
\text { small biotopes } \\
\text {-Improving the water quality } \\
\text { of an existing stream } \\
\text {-Recreation }\end{array}$ & $\begin{array}{l}\text { Qualitative } \\
\text { circumstantial } \\
\text { reasoning }\end{array}$ \\
\hline $\begin{array}{l}\text { Mertainen } \\
\text { mine }\end{array}$ & $\begin{array}{l}1,220 \text { ha (450.09 } \\
\text { Hha) of direct and } \\
\text { indirect impacts }\end{array}$ & $\begin{array}{l}\text { 2,600 ha total, of which 2,069 } \\
\text { ha 488 Hha) is used for } \\
\text { compensation }\end{array}$ & $\begin{array}{l}\text { Quantitative } \\
\text { standardised scoring } \\
\text { method }\end{array}$ \\
\hline
\end{tabular}

\subsubsection{E12 highway}

The EIA conducted a qualitative description of the ex-ante values to identify losses on the Natura 2000 area. A 'circumstantial reasoning' approach (Quétier \& Lavorel, 2011) was used, which allowed for "like-for-better" compensation. This was observed in the compensation goals of: (i) habitat for birds and small biotopes; (ii) improving water quality of an existing stream; and (iii) an attractive recreation area. These goals were then attributed objectives to facilitate implementation (see Table 4). Hence, the gain evaluations are conducted in a qualitative framework but assigned certain measurable monitoring objectives.

Table 4

Gain evaluations for a compensation goal.

\begin{tabular}{|l|l|l|l|}
\hline Goal & Objectives & Monitoring & $\begin{array}{l}\text { Monitoring } \\
\text { intervals }\end{array}$ \\
\hline
\end{tabular}




\begin{tabular}{|c|c|c|c|}
\hline \multirow{3}{*}{$\begin{array}{l}\text { Create } \\
\text { habitat for } \\
\text { birds and } \\
\text { small } \\
\text { biotopes }\end{array}$} & $\begin{array}{l}\text { Minimum five duck species and } \\
\text { six wader bird species to use } \\
\text { compensation site }\end{array}$ & $\begin{array}{l}\text { Field surveys } \\
\text { during migration } \\
\text { season }\end{array}$ & \multirow{3}{*}{$\begin{array}{l}\text { Annually for the first } \\
\text { three years, then } \\
\text { every third year }\end{array}$} \\
\hline & $\begin{array}{l}\text { Minimum one breeding pair of } \\
\text { ducks or wader birds to use } \\
\text { wetland }\end{array}$ & $\begin{array}{l}\text { Field surveys } \\
\text { during breeding } \\
\text { season }\end{array}$ & \\
\hline & $\begin{array}{l}\text { Minimum three sand martins to } \\
\text { nest in artificial slope }\end{array}$ & $\begin{array}{l}\text { Ongoing field } \\
\text { surveys }\end{array}$ & \\
\hline
\end{tabular}

Source: (Enetjärn Natur AB, 2013)

The EIA identified 19 bird species using the impact area. However, the EIA did not discuss post-impact values and therefore we are unable to assess the losses at the impact site. The development of the E12 highway has been delayed due to bureaucratic reasons; hence, no empirical data is available to assess achievement of NNL. Ex-post monitoring is needed to determine if the impact site is used by any of the 19 bird species after the development has occurred. The compensation plan is based on a problem-solving approach that allows for flexibility in implementation, but lacks detailed information on equivalency.

\subsubsection{Mertainen Mine}

Mertainen is the first case in Sweden to develop its own measurement unit for forest and wetland landscapes. The sum of losses was based on what Quétier \& Lavorel (2011) refer to as a quantitative 'standardised scoring method', using an 'area x quality' metric called Habitat hectares (Hha). Firstly, four habitat types were identified at the impact site. Each habitat was categorised into three condition classes (Highest, High and Ordinary natural values). An example of the calculations for one habitat type is presented in Table 5 (based on Tables C.1 and C.2 in Appendix C). This habitat type covered 156 ha, where 31 ha was Class 1 condition (Highest natural value) and 125 ha of Class 2 (High natural value).

Secondly, certain key ecological attributes for the habitat type were selected as indicators. A protected eco-park served as a reference point with pristine natural values. Environmental consultants allocated each attribute a predefined weighted percentage and conducted field studies to determine the impact site score. The final sum of all attributes is then multiplied by the predefined weight. The calculations indicated that the Class 1 quality value of this habitat type at pre-impact Mertainen corresponds to $70 \%$ of the eco-park benchmark value (see Appendix C, Table C.2), while Class 2 corresponded to $36 \%$.

Thirdly, Habitat Hectares were calculated for pre- and post-impact based on the forecasted impact degrees. Three categories of impact degrees were defined: High (direct impacts with $100 \%$ reduction in biodiversity values), Medium (buffer zone with $75 \%$ reduction) and Low (indirect impacts beyond buffer zone with 30\% reduction). The formulas used in Table 5 are as follows:

Habitat Hectares pre-impact $=$ Area $x$ Quality Value

Habitat Hectares post-impact $=$ Area $\mathrm{x}$ Quality Value $\mathrm{x} \%$ of Impact Degree

Table 5

Habitat Hectares calculation of 'old growth forest rich in broad leaves' habitat type.

\begin{tabular}{|l|l|l|l|l|l|l|}
\hline $\begin{array}{l}\text { Condition } \\
\text { class }\end{array}$ & $\begin{array}{l}\text { Area } \\
\text { (ha) }\end{array}$ & $\begin{array}{l}\text { Habitat } \\
\text { Hectares pre- } \\
\text { impact (Hha) }\end{array}$ & $\begin{array}{l}\text { High } \\
\mathbf{( 1 0 0 \% )}\end{array}$ & $\begin{array}{l}\text { Medium } \\
\mathbf{( 7 5 \% )}\end{array}$ & $\begin{array}{l}\text { Low } \\
\mathbf{( 3 0 \% )}\end{array}$ & $\begin{array}{l}\text { Hectares } \\
\text { lost (Hha) }\end{array}$ \\
\hline
\end{tabular}




\begin{tabular}{|l|l|l|l|l|l|l|}
\hline Class 1 & 30.8 & $\begin{array}{l}30.8 \times 0.7= \\
21.67\end{array}$ & $\begin{array}{l}0.9 \times 0.7 \times \\
1=0.63\end{array}$ & $\begin{array}{l}7.4 \times 0.7 \times \\
0.75=3.91\end{array}$ & $\begin{array}{l}22.5 \times 0.7 \\
\times 0.3= \\
4.75\end{array}$ & 9.29 \\
\hline Class 2 & 125.3 & $\begin{array}{l}125.3 \times 0.36 \\
=44.62\end{array}$ & $\begin{array}{l}28.1 \times 0.36 \\
\times 1=10.01\end{array}$ & $\begin{array}{l}16.5 \times 0.36 \\
\times 0.75= \\
4.41\end{array}$ & $\begin{array}{l}80.7 \times \\
0.36 \times \\
0.3=8.62\end{array}$ & 23.03 \\
& & & \multicolumn{3}{|l|}{} & $\mathbf{3 2 . 3 2}$ \\
\hline
\end{tabular}

Note. Figures are approximate as decimal points are included.

Source: Enetjärn Natur AB (2014b).

Hence, 156 ha corresponds to 66.29 Hha as the value of this habitat type at pre-impact Mertainen. 32.32 Hha represents the lost values to be compensated. The final step is to determine the total Hha lost for all habitat types (Table 6).

Table 6

Total estimated losses at Mertainen in Hha.

\begin{tabular}{|l|r|r|r|}
\hline Habitat type & $\begin{array}{l}\text { Biodiversity value } \\
\text { pre-impact, C (Hha) }\end{array}$ & $\begin{array}{l}\text { Biodiversity value } \\
\text { lost, D (Hha) }\end{array}$ & $\begin{array}{l}\text { Predicted } \\
\text { remaining post-impact, } \\
\text { C - D (Hha) }\end{array}$ \\
\hline $\begin{array}{l}\text { Old growth forest } \\
\text { rich in broad } \\
\text { leaves }\end{array}$ & 66.29 & 32.32 & 33.97 \\
\hline $\begin{array}{l}\text { Old growth } \\
\text { coniferous forest }\end{array}$ & 376.78 & 272.46 & 104.32 \\
\hline $\begin{array}{l}\text { Forest-wetland } \\
\text { mosaic }\end{array}$ & 70.16 & 30.16 & 40 \\
\hline Wetlands & 146.63 & 115.15 & 31.48 \\
\hline Total & 659.86 & $\mathbf{4 5 0 . 0 9}$ & 209.77 \\
\hline
\end{tabular}

Note. Figures are approximate as decimal points are included.

Source: Enetjärn Natur AB (2014b).

As seen in Table 6, 450.09 Hha was calculated as the sum of losses at Mertainen and represents the minimum value to be gained at the compensation site. The same methodology was then used to determine the Hha present at the compensation site. Although only 450 Hha are lost at Mertainen, 488 Hha will be compensated as the additional 38 Hha accounts for uncertainty (see Appendix C, Table C.3 and C.4). Of the 488 compensatory Hha, 424 Hha are attributed to protection and 64 Hha are attributed to restoration activities such as increasing dead wood and controlled burning (Zachrisson, pers. comm.). Even if additionality is achieved by instating Kuosajänkkä as a nature reserve after the 50 years (Alt. A in Fig. 3), NNL would still not be achieved because the baseline scenario is 424 Hha losses from forestry (see Fig. 3). Alt. B illustrates the option that forests are cut after 50 years. 


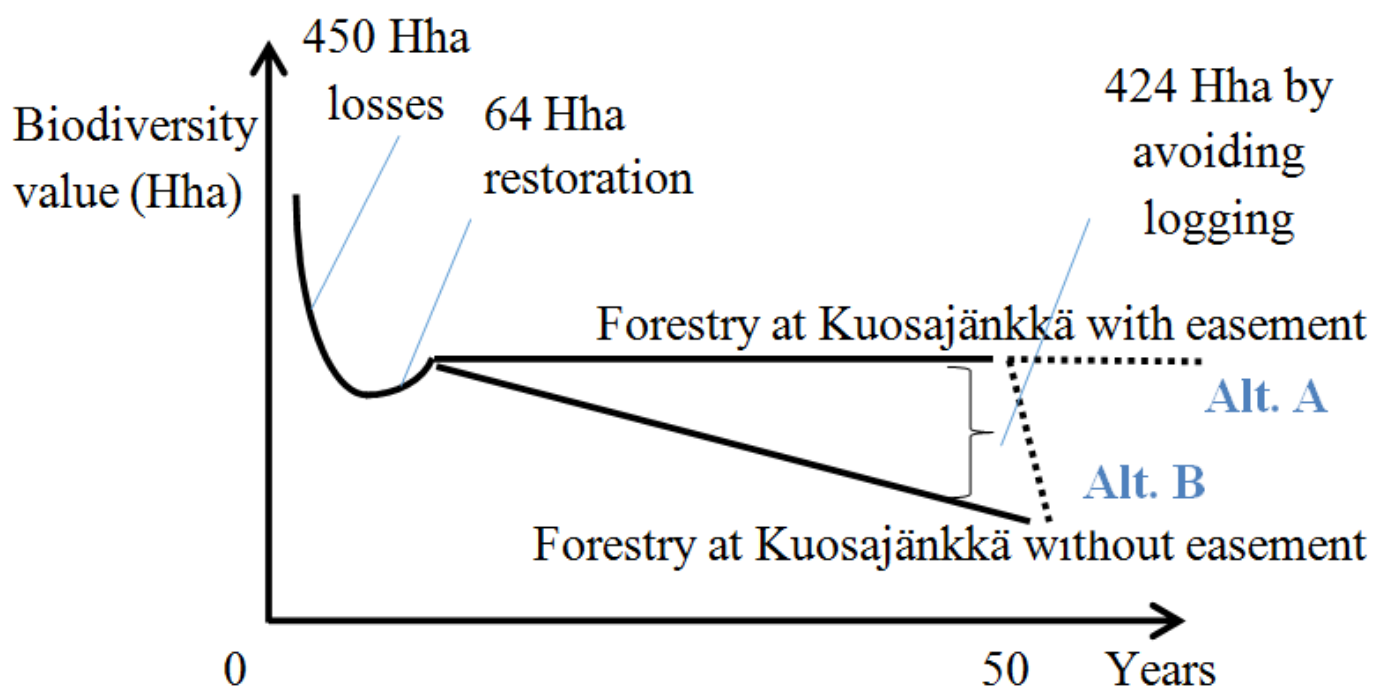

Fig. 3. 450 Hha losses from mining are compensated by 64 Hha of restoration activities and 424 Hha of conservation, compared to if the forests at Kuosajänkkä otherwise would be clear-cut during the 50 year-period. Biodiversity values at Kuosajänkkä were not assumed by the environmental consultants to increase over time if protected. Hence, NNL is not achieved even if Kuosajänkkä becomes a nature reserve after 50 years.

\subsection{Social safeguards}

According to Chapter $1 \S 2$ of the Swedish Constitution, opportunities for the Sami people to maintain and develop their culture and social life should be promoted. Complementary to the international human rights instruments, including the United Declaration of the Rights of Indigenous Peoples (UNDRIP) and EC specific instruments such as the BBOP (2009), the CBD guidelines in BFMs (see Table 7 and Appendix A) are part of the legal landscape for EC to achieve social and ecological objectives. This was also noted during the 2016 Conference of the Parties meeting on Resource mobilization, as a part of the monitoring and sharing of lessons learned from the implementation of these CBD guidelines at the national level. ${ }^{x}$ The CBD Subsidiary Body of Implementation will make recommendations for the implementation of these CBD Guidelines for "addressing effectively the potential impacts of biodiversity financing mechanisms on different elements of biodiversity, as well as their potential effects on the rights and livelihoods of indigenous peoples and local communities for consideration by the Conference of the Parties at its fourteenth meeting".

Hence, EC may impact the provision of cultural ecosystems services, thereby impacting the wellbeing and rights of distinct individuals and groups. There are two groups of right holders whose rights are at risk with EC: (1) those at the impact site that may face reduced access after development and (2) those at the compensation site that may suffer if exclusionary conservation approaches are applied. In either case, this would result in reduced access and possibility to benefit from natural resources; thereby affecting people's rights. The EC literature has noted certain social values, rights to resources and safeguards that are relevant when dealing with relocation of biodiversity (Brownlie et al., 2013; Ituarte-Lima et al., 2014). Based on these values, we focus on two different social safeguards vital to each case: safeguarding people's wellbeing though access to recreation for E12 and safeguarding cultural rights and rights over natural resources for Mertainen. Participation is also briefly assessed for both cases.

\subsubsection{Safeguarding people's wellbeing though access to recreation}

According to Chapter 14 of the Swedish Road Law, road projects must be announced in advance and made available for public appeal. This standard procedure was followed in the E12 
case. Barriers to recreation were discussed, the Swedish Society for Nature Conservation (SSNC) [Naturskyddsföreningen] (2009) emphasised in its appeal that the highway would compromise recreational values. As the impact site had been used for recreation by the neighbouring housing community (Trafikverket, 2011), the project ensured that reasonable access to recreation is maintained through on-site measures such as pedestrian crossings aligned with existing walking paths. Proximity to the impact site was also an explicit criterion for the compensation. Still, the five $\mathrm{km}$ distance makes it inevitable that different housing communities are affected. These communities are noted to have similar socio-economic standards (Grellmann, pers. comm.).

The compensation plan aims to increase the social value of the site through walking paths, cycle routes and resting areas in an aesthetic environment. Overall, the impact site community maintains reasonable access to recreation, while the compensation site community gains an improved recreational site. There is no ambition from the municipality to present it as compensation for the impact site's social values, nor the expectation that the impact site community will travel five $\mathrm{km}$ to use the compensation site (Grellman, pers. comm.). The compensation mainly serves the purpose of helping to finance the municipality's green infrastructure planning.

\subsubsection{Safeguarding cultural rights and rights over natural resources}

The right to herd reindeer is an important part of the indigenous Sami people traditions and essential to their livelihoods (Hahn, 2000); as acknowledged in Chapter $1 \S 2$ of the Swedish constitution. However, the International Convention on Civil and Political Rights (ICCPR) ${ }^{\mathrm{xi}}$ Committee (2009) and the United Nations Human Rights Council's (2016) Report of the Special Rapporteur on indigenous peoples have recommended Sweden to take further measures for adequately defining and recognizing the Sami peoples' cultural rights and rights over natural resources, which are vital for their livelihoods. For instance, the Special Rapporteur on the rights of indigenous peoples in its mission report on the human rights situation of the Sami people notes that "Unlike its Finnish and Norwegian counterparts, the Minerals Act does not include any explicit references to Sami rights" (2016, par. 40, page 12). The recommendations to Sweden by the special Rapporteur includes a revision of its Minerals Act to ensure it is in compliance with international human rights standards and refers to adequate consultations with affected indigenous communities, mitigation measures, compensation as well as fair and equitable benefit-sharing.

In Mertainen, the Gabna Sami community faces direct impacts as their grazing land is used for rock deposits and mining operations. Indirect impacts of increased noise, traffic and dust renders areas nearby the mining zone unusable. The Laevas Sami community is threatened by indirect impacts, as the impact area encroaches upon a reindeer migratory route that has been used for over 200 years. Forests with abundant lichen cover provide the main feed for reindeer during winter. These have declined by $71 \%$ during the last 60 years and become spatially fragmented (Sandström et al., 2016). Limited grazing land also increases the need for supplementary feeding, which subsequently incurs costs for the communities.

In 2012, LKAB signed a major agreement with these two Sami communities. This represents a commitment by the developer to compensate for reindeer husbandry losses caused by mining activities. All future mining operations must adhere to this agreement, which the Sami had requested for decades (Inga, pers. comm.). For each intrusion into reindeer husbandry, LKAB committed to collaborate with the Sami communities in monthly consultations to reach a solution that minimises interference (LKAB vs. CAB Norrbotten et al., 2013a, p. 49). The agreement influenced mitigation issues such as the location of operations, a wildlife passage and monetary compensation for additional costs incurred such as feeding (Eriksson, pers. comm.).

However, the compensation plan only concerned biodiversity-related issues. Although a 50 -year moratorium on forestry will benefit reindeer husbandry, the compensation plan did not 
consider benefit sharing between the two Sami communities (LKAB vs. CAB Norrbotten et al., 2014, p. 5). Kuosajänkkä is coincidentally situated in the Gabna Sami community, which suffers most from the impacts. Despite the agreement and the compensation, the expanded mining will still result in further losses of grazing land and physical obstacles. Even if the additional costs are paid for by LKAB, this cannot substitute for the losses of land and that is why the Sami oppose mining (Inga, pers. comm.).

\section{Discussion}

\subsection{License-to-trash}

The Avoidance step of the mitigation hierarchy is regulated by legislation. The case studies do not suggest that the compensation instrument has influenced this legal process, since the practitioners showed reasonable awareness of this risk. The recent SEPA (2016) compensation guidelines emphasise that compensation should not interfere with the approval process, although clear legislation on EC is still lacking in Sweden. EC can never substitute a solid legislation that protects valuable areas from development; just as economic (incentive-based) instruments are complementary, thereby requiring legislation to be effective (Vatn, 2005; Hahn et al., 2015).

Concerning additionality, the Mertainen case exemplifies the difficulty in compensating for old-growth forests. Additionality based on conservation (preventing expected degradation) does not achieve NNL, as indicated in Fig. 3. As Pilgrim and Ekstrom (2014) highlight, justifying additionality on land that have prior obligations for conservation is particularly difficult to demonstrate and this could undermine the underlying principles of EC. EC policies should require the demonstration of clear additionality and address how compensation based on the preservation of already protected areas should be interpreted. With the U.S. wetland banking, Ambrose and Lee (2004, p. 12) emphasize that preservation areas should not be considered as direct compensation for permanent wetland losses while Australia's BioBanking scheme addresses NNL by choosing land with low biodiversity (therefore high potential for restoration) and protecting it for perpetuity (Conway et al., 2013, p. 118).

\subsection{Compensation pools}

EC currently occurs from a demand-side in Sweden; the developer initiates investigations for a compensation site, secures access and then proposes compensatory measures. As each project is individualised, demand-side compensation involves substantial transaction costs. Our cases illustrate the difficulty of obtaining compensation land, which has also been noted in the literature (Rundcrantz, 2006, p. 364; eftec et al., 2010b, p. 91; Persson, 2011, p. 150; SEPA, 2016).

When CABs and municipalities decide to instate nature reserves by expropriating private land, they pay landowners 125\% of the estimated land value (Expropriation Act 1972:719). Nevertheless, landowners are generally reluctant when nature reserves are proposed (Götmark, 2009). Despite guidance requiring collaboration with landowners, the process is still top-down. EC in Sweden has been similarly framed. This may explain why EC is not perceived as a business opportunity, although it was for the Jukkasjärvi Forest common in the Mertainen case.

On the other hand, supply-side compensation may increase the efficiency of land allocation for conservation, reduce costs and offer economies of scale (eftec et al., 2010b). Moreover, the values of the land in a pool can increase before development projects begin, thereby accounting for time-delays of restoration (Moilanen et al. 2009; Curran et al. 2014). As the German 'compensation pools' have shown, balancing biodiversity losses and gains can be done by third-party agencies/boards rather than developers and landowners, hence avoiding high degrees of commodification (Hahn et al., 2015). If landowners perceive EC as a business opportunity instead of a sacrifice towards nature conservation, compensation pools may be a 
strategy to enhance EC in Sweden (Enetjärn Natur AB, 2015). Moreover, if CABs and municipalities are represented in the agencies/boards responsible for compensation pools, EC could facilitate land-use planning for ecological as well as social values. The involvement of representatives from industry, landowners and conservation NGOs could also ensure legitimacy.

\subsection{Complementary qualitative and quantitative valuation methods}

EC in Sweden commonly employs a qualitative circumstantial reasoning approach, as the EIA describes biodiversity losses rather than quantifies them (Rundcrantz, 2006). Although this allows for flexibility of compensation measures as seen in the E12 case, knowledge transfer is limited and transaction costs are large.

Globally, most established EC programs use an 'area x quality' based measurement usually according to habitat type or function, which facilitates consistency and transparency. However, Mertainen demonstrates that adhering to BBOP guidelines with quantitative valuations on an ecologically complex area is no easy feat. Although BBOP endorses transparency, this was not necessarily the case with Mertainen. For those who are not environmental consultants, the complexity of the biodiversity calculations proved challenging to fully comprehend (Nilsson pers. comm.). Using a unit to measure biodiversity will always have its risks; there is no perfect measurement that can account for the complexities of biodiversity values (Pilgrim \& Ekstrom, 2014). To handle these risks, the compensation agencies/boards need to incorporate an inclusive stakeholder participation process.

Since compensation projects in Sweden are often based on what can be agreed to by the court and developer, its objectives may be lower than what should actually be required for NNL. It is unlikely that compensation measures contingent on ambitions of developers would be able to achieve NNL on a nationwide scale. The legal framework needs to ensure that quantitative methods support the assessment of additionality and provide a baseline for NNL to be measured against.

\subsection{Integrating social safeguards}

Despite the three CBD objectives that integrate social and ecological concerns, compensation projects in Sweden have so far focused on biodiversity values rather than social values (Rundcrantz, 2006). There have been no cases where the courts have required compensation for impacts on social, cultural or recreational values (Lerman, 2014, p. 44). Our findings demonstrate the importance of the EIA, which serves as the preliminary platform for considering social values. A social impact assessment could be integrated with the EIA to assess what actors use the ecosystems at impact and compensation sites. Social-ecological inventories have been used by (Schultz et al., 2007) to assess ecosystem processes, its local use and management. We have identified two social safeguards that are especially relevant to the case studies: safeguarding people's wellbeing though access to recreation for urban people in the E12 highway case, and safeguarding tenure/resources rights that are intertwined with cultural rights of the Sami people in the case of the Mertainen mine. The latter is also relevant for rural and forest communities who depend on ecosystems, such as tourism. A lesson from Mertainen is that when complex property rights and equity issues are at stake, an in-depth investigation for operationalising social safeguards including socio-ecological related human rights and compensation of social values should be required. Integrating both biodiversity and social safeguards is especially important when selecting the compensation site and appropriate restoration measures.

\subsection{Synchronising biodiversity and social safeguards}

As mentioned in the introduction, the voluntary CBD guidelines for safeguards in BFMs (see Appendix A; summarised in Table 7) are useful for synchronising biodiversity and social 
safeguards (Convention on Biological Diversity (CBD), 2014) to promote resilience of socialecological systems. In line with these guidelines, we find that instrument-specific safeguards (in this case for EC) embedded in national legislation are key for operationalising social and ecological goals associated with BFMs. Furthermore, our case studies reveal important lessons learned and challenges that emerge in the implementation of BFM safeguards (see Table 7).

\section{Table 7}

The CBD guidelines and lessons learned from the operationalisation of safeguards in EC in Sweden.

\begin{tabular}{|c|c|c|c|c|}
\hline $\begin{array}{l}\text { CBD (2014) } \\
\text { Guidelines } \\
\text { for } \\
\text { safeguards in } \\
\text { Biodiversity } \\
\text { Financing } \\
\text { Mechanisms }\end{array}$ & $\begin{array}{l}\text { a) Biodiversity } \\
\text { values and } \\
\text { ecosystem } \\
\text { functions }\end{array}$ & $\begin{array}{l}\text { b) People's } \\
\text { rights, access } \\
\text { to resources, } \\
\text { and } \\
\text { livelihoods }\end{array}$ & $\begin{array}{l}\text { c) Local and } \\
\text { country- } \\
\text { driven/specific } \\
\text { processes linked } \\
\text { to the } \\
\text { international } \\
\text { level }\end{array}$ & $\begin{array}{l}\text { d) Governance, } \\
\text { enforcement and } \\
\text { accountability }\end{array}$ \\
\hline $\begin{array}{l}\text { Examples of } \\
\text { legal } \\
\text { instruments } \\
\text { applicable in } \\
\text { Sweden }\end{array}$ & $\begin{array}{l}\text { Mitigation } \\
\text { hierarchy: a } \\
\text { specific } \\
\text { biodiversity } \\
\text { safeguard for EC } \\
\text { (Chapter } 2 \S 6 \\
\text { and } 2 \S 7 \text { of the } \\
\text { Environmental } \\
\text { Code). }\end{array}$ & $\begin{array}{l}\text { Participation } \\
\text { rights and } \\
\text { heightened } \\
\text { protection of } \\
\text { Sami people's } \\
\text { and other } \\
\text { ethnic } \\
\text { minorities' } \\
\text { cultural rights } \\
\text { (Constitution } \\
\text { Chapter 1§2). }\end{array}$ & $\begin{array}{l}\text { Need to articulate } \\
\text { the Environmental } \\
\text { Code, e.g. Chapter } \\
16 \S 9 \text {, with the } \\
\text { Swedish } \\
\text { Constitution and } \\
\text { international } \\
\text { instruments, e.g. } \\
\text { CBD Guidelines, } \\
\text { human rights law } \\
\text { including UNDRIP. }\end{array}$ & $\begin{array}{l}\text { Developer obliged } \\
\text { to conduct an EIA. } \\
\text { If the permit is } \\
\text { approved, the } \\
\text { mitigation } \\
\text { hierarchy and its } \\
\text { enforcement is } \\
\text { required (Chapter } \\
16 \S 9 \text { and } 26 \text { of the } \\
\text { Environmental } \\
\text { Code). }\end{array}$ \\
\hline $\begin{array}{l}\text { Lessons } \\
\text { learned } \\
\text { concerning } \\
\text { safeguards in } \\
\text { E12 highway } \\
\text { case }\end{array}$ & $\begin{array}{l}\text { Swedish Road } \\
\text { Law lacks EC } \\
\text { legal provisions } \\
\text { unless } \\
\text { development is } \\
\text { in protected } \\
\text { areas. }\end{array}$ & $\begin{array}{l}\text { Public } \\
\text { consultation } \\
\text { and EIA } \\
\text { (Swedish Road } \\
\text { Law §14) } \\
\text { should be } \\
\text { done early in } \\
\text { the planning } \\
\text { process. }\end{array}$ & $\begin{array}{l}\text { EC for impacts in } \\
\text { protected areas, } \\
\text { e.g. Natura 2000, } \\
\text { could support } \\
\text { financing the } \\
\text { municipality's } \\
\text { green } \\
\text { infrastructure. }\end{array}$ & $\begin{array}{l}\text { EC exemptions to } \\
\text { the development } \\
\text { of roads limit } \\
\text { enforceability of } \\
\text { safeguards. }\end{array}$ \\
\hline $\begin{array}{l}\text { Lessons } \\
\text { learned } \\
\text { concerning } \\
\text { safeguards in } \\
\text { the } \\
\text { Mertainen } \\
\text { mine case }\end{array}$ & $\begin{array}{l}\text { High } \\
\text { conservation } \\
\text { values in } \\
\text { tension with } \\
\text { mining } \\
\text { extraction; both } \\
\text { are legally } \\
\text { considered } \\
\text { "national } \\
\text { interest." }\end{array}$ & $\begin{array}{l}\text { Rights of local } \\
\text { landowners } \\
\text { are strong. } \\
\text { Lack of explicit } \\
\text { reference to } \\
\text { Sami rights in } \\
\text { the Minerals } \\
\text { Act. }\end{array}$ & $\begin{array}{l}\text { In operationalising } \\
\text { CBD and the EU's } \\
\text { NNL initiative, } \\
\text { risks of } \\
\text { biodiversity } \\
\text { leakage arise. }\end{array}$ & $\begin{array}{l}\text { Chapter } 16 \$ 9 \text { does } \\
\text { not require full } \\
\text { compensation (i.e. } \\
\text { NNL) and } \\
\text { additionality is } \\
\text { unclear. Social } \\
\text { safeguards exist } \\
\text { but were not } \\
\text { sufficiently } \\
\text { operationalised. }\end{array}$ \\
\hline
\end{tabular}

\section{Conclusion}


Having assessed four major areas of concern, we draw the following conclusions regarding the future of ecological compensation in Sweden.

Firstly, despite ambiguous legislation, the courts showed a reasonable awareness of the risks of a license-to-trash. Nevertheless, to ensure additionality and NNL, the institutional arrangements of EC need to target restoration and other forms of ecological intensification, rather than protection. Second, compensation pools offer a strategy to increase land availability and decrease transaction costs of the present ad hoc system, although proposing a policy design for this requires further research. Third, while measuring biodiversity is a never-ending controversy, the E12 highway case suggests that a flexible and pragmatic approach ("like-for-better") allows for innovative and effective solutions. This needs to co-exist with a clear legal framework of both substantive and procedural provisions. Lastly, synchronising biodiversity and social safeguards is important for ensuring positive social and ecological outcomes. Transparency in the measurements of biodiversity values and ecosystem functions used in EC, as well as how public participation is considered in decision-making is a part of this process. The means to safeguard social equity and socio-ecological related human rights, including rights of the Sami people, should be further developed in Sweden, both in the legislation and implementation of EC.

Finally, even if all of these challenges are met in Sweden or the EU, EC can never be the main instrument for conservation but a complement to an appropriate and effective legal framework that protects biodiversity and ecosystems, while ensuring the sustainable and equitable use of ecosystem services.

\section{Funding}

This work was supported by the Swedish Institute, the Swedish Research Council for Environment, Agricultural Sciences and Spatial Planning (Formas) project: 'Effective and Equitable Institutional Arrangements for Financing and Safeguarding Biodiversity' (254-2013130 ) at the Stockholm Resilience Center, Mistra Financial Systems (MFS): 'Putting financial systems to work for sustainability' (DIA 2013/39), as well as Mistra through a core grant to Stockholm Resilience Centre.

\section{Acknowledgements}

The authors would like to thank the project developers, environmental consultants, municipalities, county administrative boards, court authorities, landowners, indigenous peoples and local communities who generously contributed their time to be interviewed for this paper. A full list of key informants is available in Appendix B.

\section{References}

Ambrose, R., \& Lee, S. (2004). An evaluation of compensatory mitigation projects permitted under Clean Water Act Sect.401 by the Los Angeles Regional Quality Control Board. Los Angeles: California Regional Water Quality Control Board.

Briggs, B., Hill, D., \& Gillepsie, R. (2009). Habitat banking—how it could work in the UK. Journal for Nature Conservation, 17(2), 112-122. doi:10.1016/j.jnc.2008.12.006

Bromley, D. (1991). Environment and Economy: Property Rights. Oxford, UK: Basil Blackwell.

Brown, S., \& Veneman, P. (2001). Effectiveness of compensatory wetland mitigation in Massachusetts, USA. Wetlands, 21(4), 508-518. doi:10.1672/02775212(2001)021[0508:EOCWMI]2.0.CO;2 
Brownlie, S., King, N., \& Treweek, J. (2013). Biodiversity tradeoffs and offsets in impact assessment and decision making: can we stop the loss? Impact Assessment and Project Appraisal, 31(1), 24-33. doi:10.1080/14615517.2012.736763

Bull, J., Suttle, B., Gordon, A., Singh, N., \& Milner-Gulland, E. (2012). Biodiversity offsets in theory and practice. Fauna \& Flora International, 1-12. doi:10.1017/S003060531200172X

Burgin, S. (2010). 'Mitigation banks' for wetland conservation: a major success or an unmitigated disaster? Wetlands Ecology and Management, 18, 49-55. doi:10.1007/s11273-009-9147-5

Business and Biodiversity Offsets Programme (BBOP). (2009). Biodiversity Offset Design Handbook. Washington: Business and Biodiversity Offsets Programme. Retrieved October 5, 2016, from http://www.forest-trends.org/documents/files/doc_3126.pdf

Ciuchini, P. (2010). Developer pays...or does he? Archaeology Ireland, 24(94), 12-13.

Clare, S., Krogman, N., Foote, L., \& Lemphers, N. (2011). Where is the avoidance in the implementation of wetland law and policy? Wetlands Ecol Manage, 19, 165-182. doi:10.1007/s11273-011-9209-3

Convention on Biological Diversity (CBD). (2011). Access to Genetic Resources and the Fair and Equitable Sharing of Benefits Arising from their Utilization (ABS) to the Convention on Biological Diversity. Nagoya: Secretariat of the Convention on Biological Diversity. Retrieved 5 October, 2016, from https://www.cbd.int/abs/doc/protocol/nagoyaprotocol-en.pdf

Convention on Biological Diversity (CBD). (2014). Resource Mobilization and respective Annex III. UNEP/CBD/COP/DEC/XII/3. Montreal: Secretariat of the Convention on Biological Diversity. Retrieved 4 October, 2016, from https://www.cbd.int/doc/decisions/cop12/cop-12-dec-03-en.pdf

Conway, M., Rayment, M., White, A., \& Berman, S. (2013). Exploring potential demand for and supply of habitat banking in the EU and appropriate design elements for a habitat banking scheme. London: ICF GHK Consulting Ltd in association with BIO Intelligence Service. Retrieved 5 October, 2016, from http://ec.europa.eu/environment/enveco/taxation/pdf/Habitat_banking_Report.pdf

Cuperus, R., Canters, K., Udo de Haes, H., \& Friedman, D. (1999). Guidelines for ecological compensation associated with highways. Biological Conservation, 90, 41-51.

Curran, M., Hellweg, S., \& Beck, J. (2014). Is there any empirical support for biodiversity offset policy? Ecological Applications, 24(4), 617-632. doi:10.1890/13-0243.1

Daw, T., Brown, K., Rosendo, S., \& Pomeroy, R. (2011). Applying the ecosystem services concept to poverty alleviation: the need to disaggregate human well-being. Environmental Conservation, 38(4), 370-379. doi:10.1017/S0376892911000506

eftec et al. (2010a). The use of market-based instruments for biodiversity protection- Habitat Banking case studies. Appendix: Case Studies. London: eftec. Retrieved 5 October, 2016, from http://www.ieep.eu/assets/474/eftec_habitat_banking_case_study_appendix.pdf 
eftec et al. (2010b). The use of market-based instruments for biodiversity protection - The case of habitat banking - Summary Report. London: eftec. Retrieved 5 October, 2016, from http://ec.europa.eu/environment/enveco/pdf/eftec_habitat_technical_report.pdf

Enetjärn Natur AB. (2009). Inventering och bedömning av naturvärden Västra Länken: Planerad ny förbifart vid Umeå [Inventory and assessment of natural values of the Western Link: Planned new bypass road in Umeå ]. Umeå: Enetjärn Natur AB. Retrieved 5 October, 2016, from http://www.trafikverket.se/contentassets/7f6c22b782c643be83037d5f9b90fe1a/v_la nken_091214_lag.pdf

Enetjärn Natur AB. (2013). Västra Länken inom Umeå-projektet. Ekologisk kompensation med anledning av intrång i Natura 2000 [The Western Link in the Umeå project. Ecological Compensation infringement in Natura 2000 area]. Umeå: Enetjärn Natur AB.

Enetjärn Natur AB. (2014a). Biodiversity Offset Design- the Mertainen Case Study. Umeå: Enetjärn Natur AB. Retrieved 5 October, 2016, from http://enetjarnnatur.se/site_specific/uploaded_files/55404/biodiversity-offsetdesign_20140707_final-with-front-page.pdf

Enetjärn Natur AB. (2014b). Ett standardiserat arbetssätt för ekologisk kompensation: Tillämpning av BBOP-standarden i ett svenkt piloprojekt [A standardized approach for ecological compensation: Application of the BBOP standard in a Swedish pilot project]. Umeå: Enetjärn Natur AB.

Enetjärn Natur AB. (2015). Habitat Banking: Framtider för marknadsbaserade lösningar för biologisk mångfald 2030 [Habitat Banking: The futures of market-based solutions for Biodiversity 2030]. Stockholm: Enetjärn Natur AB. Retrieved 5 October, 2016, from http://enetjarnnatur.se/site_specific/uploaded_files/32993/habitat-banking.pdf

European Commission. (2014). No Net Loss. Retrieved 25 August, 2014, from European Commission Environment: http://eur-lex.europa.eu/legalcontent/EN/TXT/PDF/?uri=CELEX:32004L0035\&from=EN

Fidel, R. (1984). The case study method: A case study. Library Research, 6(3), 273-288.

Gardner, T. V., Brownlie, S., Ekstrom, J., Pilgrim, J., Savy, C., Stephens, R., ... Ten Kate, K. (2013). Biodiversity Offsets and the Challenge of Achieving No Net Loss. Conservation Biology, 27(6), 1254-1264. doi:10.1111/cobi.12118

Gibbons, P., \& Lindenmayer, D. (2007). Offsets for land clearing: No net loss or the tail wagging the dog? ECOLOGICAL MANAGEMENT \& RESTORATION, 8(1), 26-31. doi:10.1111/j.14428903.2007.00328.x

Glicksman, R., \& Kaime, T. (2013). A Comparative Analysis of Accountability Mechanisms for Ecosystem Services Markets in the United States and the European Union. Transnational Environmental Law, 2(2), 259-283. doi:10.1017/S2047102513000125 
Gómez-Baggethun, E., \& Muradian, R. (2015). In markets we trust? Setting the boundaries of Market-Based Instruments in ecosystem services governance. Ecological Economics, 117, 217-224. doi:10.1016/j.ecolecon.2015.03.016

Götmark, F. (2009). Conflicts in conservation: Woodland key habitats, authorities and private forest owners in Sweden. Scandinavian Journal of Forest Research, 24(6), 504-514. doi:10.1080/02827580903363545

Government Offices of Sweden. (2013). Sweden's Mineral Strategy [Sveriges mineralstrategi. För ett hållbart nyttjande av Sveriges mineraltillgångar som skapar tillväxt $i$ hela landet]. Stockholm: Ministry of Enterprise, Energy and Communications. Retrieved January 24, 2017, from http://www.regeringen.se/rapporter/2013/02/n2013.02/

Hägglund, T., \& Enetjärn, A. (2014). Ekologisk kompensation - sammanställning från två nationella konferenser [Ecological compensation - A summary from two national conferences]. Borlänge: Trafikverket.

Hahn, T. (2000). Property rights, ethics, and conflict resolution: Foundations of the Sami economy in Sweden. Uppsala: SLU. Retrieved from http://www.gbv.de/dms/sbbberlin/323388701.pdf

Hahn, T., McDermott, C., Ituarte-Lima, C., Schultz, M., Green, T., \& Tuvendal, M. (2015). Purposes and degrees of commodification: Economic instruments for biodiversity and ecosystem services need not rely on markets or monetary valuation. Ecosystem Services, 16, 74-82. doi:10.1016/j.ecoser.2015.10.012

Harrison, M., \& Paoli, G. (2012). Managing the risk of biodiversity leakage from prioritising REDD+ in the most carbon-rich forests: the case study of peat-swamp forests in Kalimantan, Indonesia. Conservation Letter, 5(4), 426-433.

Hough, P., \& Robertson, M. (2009). Mitigation under Section 404 of the Clean Water Act: where it comes from, what it means. Wetlands Ecology Management, 17, 15-33. doi:10.1007/s11273-008-9093-7

International Convention on Civil and Political Rights Committee. (2009). Concluding observations of the Human Rights Committee for the Ninety-fifth session: Sweden, U.N. Doc. $C C P R / C / S W E / C O / 6$, I 20 . New York: Human Rights Committee.

Ituarte-Lima, C., Schultz, M., Hahn, T., McDermott, C., \& Cornell, S. (2014). Biodiversity financing and safeguards: lessons learned and proposed guidelines. Stockholm: SwedBio/Stockholm Resilience Centre at Stockholm University, Information Document UNEP/CBD/COP/12/INF/27 for the 12th Conference of the Parties of the Convention on Biological Diversity in Pyeongchang Korea. ISBN 92-9225-562-2. Retrieved October 5, 2016, from http://www.cbd.int/doc/?meeting=cop-12

Jenkins, M., Scherr, S., \& Inbar, M. (2004). Markets for Biodiversity Services: Potential Roles and Challenges. Environment: Science and Policy for Sustainable Development, 46(6), 32-42. doi:10.1080/00139157.2004.10545160 
Kihslinger, R. (2008). Success of Wetland Mitigation Projects. National Wetlands Newsletter, 30(2), 14-16. Retrieved October 5, 2016, from

http://www.tetonwyo.org/compplan/LDRUpdate/RuralAreas/Additional\%20Resource s/Kihslinger\%202008.pdf

Knox, J. (2017). Report of the Special Rapporteur on the issue of human rights obligations relating to the enjoyment of a safe, clean, healthy and sustainable environment $(A / H R C / 34 / 49)$. Human Rights Council.

Koh, N. S., Hahn, T., \& Ituarte-Lima, C. (2014). A comparative analysis of ecological compensation programs : The effect of program design on the social and ecological outcomes. Uppsala: Uppsala University. Retrieved 5 October, 2016, from https://www.divaportal.org/smash/get/diva2:772933/FULLTEXT01.pdf

Kvale, S., \& Brinkmann, S. (2009). Interviews: Learning the Craft of Qualitiative Research Interviewing. London: SAGE Publications Ltd.

Lerman, P. (2014). Kapitel 3: Kompensation för kulturmiljöintresse [Chapter 3: Compensation for cultural environmental interests]. In B. Danielson, P. Lerman, J. Nordblad, M. Rönn, S. Swedberg, B. Grahn Danielson, N. Rönn, \& S. Swedberg (Eds.), Kulturarv $i$ samhällsplaneringen - Kompensation av kulturmiljövärden (pp. 39-82). Stockholm: Rio Kulturlandskapet and KTH/Arkitektur. Retrieved 5 October, 2016, from http://www.kulturland.se/wp-content/uploads/2014/12/Kompensation_low.pdf

Lerman, P., \& Hedlund, A. (2013). Miljökvalitetsnormer om luft i planering och rättstillämpning. Skåne, Stockholm and Västra Götaland: Länsstyrelsen. Retrieved 5 October, 2016, from http://www.lansstyrelsen.se/stockholm/SiteCollectionDocuments/Sv/publikationer/2 013/MKN-luft-tillampning-huvudrapport-KLAR-web.pdf

LKAB. (2012). Svappavaara-Mertainen Miljökonsekvensbeskrivning Ansökan om tillstånd till fullskalig brytning [Svappavaara-Mertainen environmental impact assessment application for permission to full-scale mining]. Luleå: LKAB. Retrieved from http://www.kiruna.se/PageFiles/12903/12-725\%20SvappavaaraMertainen\%20Milj\%C3\%B6konsekvensbeskrivning\%20Ans\%C3\%B6kan\%20om\%20til lst $\%$ C3\%A5nd\%20till\%20fullskalig\%20brytning.pdf?epslanguage=sv

LKAB. (2012). Svappavaara-Mertainen Miljökonsekvensbeskrivning Ansökan om tillstånd till fullskalig brytning [Svappavaara-Mertainen environmental impact assessment application for permission to full-scale mining]. Luleå: LKAB.

LKAB vs CAB Norrbotten, M595-12 (Umeå District Court: Land and Environmental Court 3 July, 2013b). Retrieved from https://www.naturvardsverket.se/upload/stod-imiljoarbetet/remisser-och-yttranden/tidigare/yttranden-2013/ny-gruva-imertainen/Deldom-mark-miljodomstolen-mertainen-130703.pdf

LKAB vs. CAB Norrbotten et al., M 595-12 (Umeå District Court: Land and Environmental Court 10 December, 2013a). Retrieved from https://www.naturvardsverket.se/upload/stod-imiljoarbetet/rattsinformation/rattsfall/gruvor/mertainen/mmd-deldom-tillstand2013-12-10.pdf 
LKAB vs. CAB Norrbotten et al., M 595-12 (Umeå District Court: Land and Environmental Court 25 September, 2014).

Madsen, B., Carroll, N., Kandy, D., \& Bennett, G. (2011). Update: State of biodiversity markets report: offset and compensation programs. Washington: Forest Trends. Retrieved 5 October, 2016, from http://www.forest-trends.org/documents/files/doc_2848.pdf

McDermott, M., Mahanty, S., \& Schreckenberg, K. (2013). Examining equity: A multidimensional framework for assessing equity in payments for ecosystem services. Environmental Science and Policy, 33, 416-427. doi:10.1016/j.envsci.2012.10.006

McKenney, B., \& Kiesecker, J. (2010). Policy Development for Biodiversity Offsets: A Review of Offset. Environmental Management, 45, 165-176. doi:10.1007/s00267-009-9396-3

Millennium Ecosystem Assessment. (2005). Ecosystems and Human Well-being: Biodiversity Synthesis. Washington, DC: Island Press. Retrieved 5 October, 2016, from http://www.millenniumassessment.org/documents/document.356.aspx.pdf

Moilanen, A., van Teeffelen, A., Ben-Haim, Y., \& Ferrier, S. (2009). How Much Compensation is Enough? A Framework for Incorporating Uncertainty and Time Discounting When Calculating Offset Ratios for Impacted Habitat. Restoration Ecology, 17(4), 470-478. doi:10.1111/j.1526-100X.2008.00382.x

OECD. (1972). The Polluter Pays Principle. Paris: Organisation for Economic Co-operation and Development.

Persson, J. (2011). Att förstå miljökompensation [To understand environmental compensation]. Göteborg: Melica Media. Retrieved October 5, 2016, from https://www.slu.se/globalassets/.gamla_strukturen/externwebben/ltj-fakdok/landskapsarkitektur-planering-och-forvaltning/personal/cv/jesperpersson/projekt/litteraturtips/persson_j_121220-att-forsta-miljokompensation.pdf

Persson, J. (2014, February 10). Miljökompensation vid väg- och järnvägsprojekt - identifiering av status, problem och möjligheter. Alnarp: Faculty of Landscape Planning, Horticulture and Agricultural Science. Retrieved October 5, 2016, from Sveriges lantbruksuniversitet: Institutionen för landskapsarkitektur, planering och förvaltning: https://www.slu.se/globalassets/.gamla_strukturen/externwebben/ltj-fakdok/landskapsarkitektur-planering-och-forvaltning/persson-miljokompensation-ltvrapport-2014-24-15-01-16.pdf

Pilgrim, J. D., \& Ekstrom, J. M. (2014). Technical conditions for positive outcomes from biodiversity offsets. An input paper for the IUCN Technical Study Group on Biodiversity Offsets. Gland: International Union for Conservation of Nature. Retrieved 5 October, 2016, from http://www.forest-trends.org/documents/files/doc_4776.pdf

Quétier, F., \& Lavorel, S. (2011). Assessing ecological equivalence in biodiversity offset schemes: Key issues and solutions. Biological Conservation, 144, 2991-2999. doi:10.1016/j.biocon.2011.09.002 
Ruhl, J., \& Salzman, J. (2006). The effects of wetland mitigation banking on people. National Wetlands Newsletter, 28(2), 9-14.

Rundcrantz, K. (2006). Environmental Compensation in Swedish Road Planning. European Environment, 16(6), 350-367. doi:10.1002/eet.429

Rundcrantz, K., \& Skärbäck, E. (2003). Environmental Compensation in Planning: A Review of Five Different Countries With Major Emphasis on the German System. European Environment, 13(4), 204-226. doi: 10.1002/eet.324

Sands, P., \& Peel, J. (2012). Principles of International Environmental Law (3rd ed.). Cambridge: Cambridge University Press.

Sandström, P., Cory, N., Svensson, J., Hedenås, H., Jougda, L., \& Brochert, N. (2016). On the Decline of Ground Lichen Forests in the Swedish Boreal Landscape - Implications for Reindeer Husbandry and Sustainable Forest Management. Ambio, 45(4), 415-429. doi:10.1007/s13280-015-0759-0

Schultz, L., Folke, C., \& Olsson, P. (2007). Enhancing ecosystem management through socialecological inventories: lessons from Kristianstads Vattenrike, Sweden. 34(2), 140-152. doi:10.1017/S0376892907003876

Schultz, M., Berg, L., Hahn, T., \& Hård af Segerstad, L. (2013). Synliggöra värdet av ekosystemtjänster: Åtgärder för välfärd genom biologisk mångfald och ekosystemtjänster [Highlighting the value of ecosystem services: Measures for welfare through biodiversity and ecosystem services]. Stockholm: Statens Offentliga Utredningar. Retrieved October 5, 2016, from http://www.regeringen.se/contentassets/ba53cd9f18b74f348eb0ff31e8280d60/synlig gora-vardet-av-ekosystemtjanster-sou-201368

Schultz, M., Hahn, T., Hällström, N., \& Ituarte-Lima, C. (in review). The biggest single opportunity we have is dialogue: Dialogue seminars as a methodology for transformative social learning and conflict resolution. International Journal of Biodiversity Science, Ecosystem Services \& Management.

SEPA. (2012). Grön infrastruktur: Redovisning av regeringsuppdrag [Green infrastructure: A report of government assignments]. Stockholm: Naturvårdsverket.

SEPA. (2015). Tillämpning av miljöbalkens bestämmelser om ekologisk kompensation: En kartläggning [Application of the Environmental Code's provisions on ecological compensation: A survey]. Stockholm: Naturvårdsverket. Retrieved 5 October, 2016, from https://www.naturvardsverket.se/Documents/publikationer6400/978-91-620-66673.pdf?pid=14773

SEPA. (2016). Ekologisk Kompensation: En vägledning om kompensation vid förlust av naturvärden. Stockholm: Naturvårdsverket. Retrieved 5 October, 2016, from http://www.naturvardsverket.se/Documents/publikationer6400/978-91-620-01797.pdf?pid=17257 
Sullivan, S., \& Hannis, M. (2015). Nets and frames, losses and gains: Value struggles in engagements with biodiversity offsetting policy in England. Ecosystem Services, 15, 162173. doi:10.1016/j.ecoser.2015.01.009

Swedish Society for Nature Conservation (SSNC) [Naturskyddsföreningen]. (2009). Överklagande av Vägverkets beslut med beteckning PP30-A 2008:78009. Umeå: Naturskyddsföreningen. Retrieved October 4, 2016, from https://realistiskekonomi.files.wordpress.com/2012/10/slutlig-c3b6verklagannl09.pdf

Trafikverket. (2011). Miljökonsekvensbeskrivning Arbetsplan: Umeåprojektet - Västra Länken, entreprenad 9 Väg E12, delen Röbäcksdalen - Röbäck [Environmental impact assessment work plan: The Umeå project - The West Link, construction 9 Route E12, the RöbäcksdalenRoback part]. Umeå: Trafikverket. Retrieved 13 May, 2015, from http://www.trafikverket.se/PageFiles/15104/110203_mkb_e9_v_lanken_kompletterad _omarkerad_s.pdf

Trafikverket vs. CAB Västerbotten, 521-7189-2010 (Länsstyrelsen Västerbotten 17 October, 2011). Retrieved 13 May, 2015, from http://www.slu.se/Documents/externwebben/ltjfak-

dok/Landskapsarkitektur,\%20planering\%20och\%20f\%C3\%B6rvaltning/Personal/CV/ Jesper\%20Persson/Projekt/Fallen\%20i\%20TRV\%20projektet/4_\%20R\%C3\%B6b\%C3 \%A4ck\%20-\%20R\%C3\%B6b\%C3\%A4cksdalen\%20V\%C3\%A4stra\%20l\%C3\%A4nken

Tucker, G., Allen, B., Conway, M., Dickie, I., Hart, K., Rayment, M., ... van Teeffelen, A. (2013). Policy Options for an EU No Net Loss Initiative. London: Institute for European Environmental Policy. Retrieved 5 October, 2016, from https://www.cbd.int/financial/offsets/eu-nonetlossoptions.pdf

UN Human Rights Council. (2016). Report of the Special Rapporteur on the rights of indigenous peoples on the human rights situation of the Sami people in the Sápmi region of Norway, Sweden and Finland. UN Human Rights Council. Retrieved October 18, 2016, from https://documents-ddsny.un.org/doc/UNDOC/GEN/G16/175/50/PDF/G1617550.pdf?OpenElement

Vägverket. (2003). Alternativa E4- och E12- förbindelser vid Umeå-Umeåprojektet 2- inom Natura 2000-området Umeälvens delta och slätter [Alternative E4- and E12- connections at Umeå: The Umea project 2 within the Natura 2000 area of Umea River delta and plains]. Umeå: Vägverket Region Norr.

Vatn, A. (2015). Markets in environmental governance: From theory to practice. Ecological Economics, 105, 97-105. doi:10.1016/j.ecolecon.2014.07.017

Wende, W., Herberg, A., \& Herzberg, A. (2005). Mitigation banking and compensation pools: improving the effectiveness of impact mitigation regulation in project planning procedures. Impact Assessment and Project Appraisal, 23(2), 101-111. doi:10.3152/147154605781765652 
Willems, J. (2007). The Work of Making Malta: the Council of Europe's Archaeology and Planning Committee 1988-1996. European Journal of Archaeology, 10(1), 57-71. doi:10.1177/1461957108091482

Yin, R. (1994). Discovering the Future of the Case Study Method in Evaluation Research. Evaluation Practice, 15(3), 283-290. doi:10.1016/0886-1633(94)90023-X

\section{Appendix A}

\section{Box A.1}

$\begin{array}{lccccc}\text { VOLUNTARY } & \text { CBD } & \text { GUIDELINES } & \text { ON } & \text { SAFEGUARDS } & \text { IN } \\ \text { BIODIVERSITY FINANCING } & \text { MECHANISMS } & & \end{array}$

(a) The role of biodiversity and ecosystem functions for local livelihoods and resilience, as well as biodiversity's intrinsic values, should be recognised in the selection, design and implementation of biodiversity financing mechanisms;

(b) Rights and responsibilities of actors and/or stakeholders in biodiversity financing mechanisms should be carefully defined, at national level, in a fair and equitable manner, with the effective participation of all actors concerned, including the prior informed consent or approval and involvement of indigenous and local communities, taking into account, the Convention on Biological Diversity and its relevant decisions, guidance and principles and, as appropriate, the United Nations Declaration of the Rights of Indigenous Peoples;

(c) Safeguards in biodiversity financing mechanisms should be grounded in local circumstances, be developed consistent with relevant country-driven/specific processes as well as national legislation and priorities, and take into account relevant international agreements, declarations and guidance, developed under the Convention on Biological Diversity and as appropriate, the United Nations Framework Convention on Climate Change, international human rights treaties and the United Nations Declaration of the Rights of Indigenous Peoples, among others;

(d) Appropriate and effective institutional frameworks are of utmost importance for safeguards to be operational and should be put in place, including enforcement and evaluation mechanisms that will ensure transparency and accountability, as well as compliance with relevant safeguards.

\section{Appendix B}

\section{Personal Communications with Key Informants}

The E12 Highway case

- $\quad$ Anders Enetjärn, CEO of Enetjärn Natur AB

- Joacim Jacobsson, Environmental Officer at CAB Västerbotten

- Stig Rönnlund, Operations Leader at Forslunda agricultural college

- Ingvar Mosesson, Project Leader at Trafikverket

- Jonas Jonsson, Environmental Specialist at Trafikverket

- Doris Grellmann, Nature Conservation Planner at Umeå Municipality

The Mertainen mine case 
- $\quad$ Nic Kruys, Project Leader at Enetjärn Natur AB

- $\quad$ Kirsi Jokinen, Consultant at Enetjärn Natur AB

- Therese Wikström, Division for Environmental Protection at CAB Norrbotten

- Henrik Bergström, Technical Judge at the Land and Environmental Court of Umeå District Court

- Anders Alenskär, Judge at the Land and Environmental Court of Umeå District Court

- Lena Nilsson, Technical Judge at the Land and Environmental Court of Umeå District Court

- $\quad$ Annika Zachrisson, Project Leader for the External Environment at LKAB

- Stina Eriksson, Project Leader for Sustainability at LKAB

- Linda Bjurholt, Environmental Manager at LKAB

- Anders Fjällborg, Environmental Manager at Kiruna municipality

- Niila Inga, Chairperson of the Laevas Sami community

- Lars-Eric Kuhmunen, Chairperson of the Gabna Sami community

- Torsten Johansson, Chairperson of Jukkasjärvi forest commons

\section{Appendix C}

Table C.1.

Total impact area per condition class of 'old growth forest rich in broad leaves' in ha.

\begin{tabular}{|c|c|c|c|c|}
\hline \multirow{2}{*}{$\begin{array}{c}\text { Condition } \\
\text { Class }\end{array}$} & $\begin{array}{c}\text { Total impact area per } \\
\text { condition class (ha) }\end{array}$ & \multicolumn{3}{|c|}{ Impact degree (ha) } \\
\cline { 3 - 5 } & & $\begin{array}{c}\text { High } \\
(\mathbf{1 0 0 \% )}\end{array}$ & $\begin{array}{c}\text { Medium } \\
\mathbf{( 7 5 \% )}\end{array}$ & $\begin{array}{c}\text { Low } \\
\mathbf{( 3 0 \% )}\end{array}$ \\
\hline Class 1 & 30.8 & 0.9 & 7.4 & 22.5 \\
\hline Class 2 & 125.3 & 28.1 & 16.5 & 80.7 \\
\hline $\begin{array}{l}\text { Total impact } \\
\text { (ha) }\end{array}$ & $\mathbf{1 5 6 . 1}$ & $\mathbf{2 9}$ & $\mathbf{2 3 . 9}$ & $\mathbf{1 0 3 . 2}$ \\
\hline
\end{tabular}

Note: Class 1 is Highest natural value, Class 2 is High natural value and Class 3 is Ordinary natural value. Data was only available for Class 1 and 2 of this particular habitat type.

Source: Enetjärn Natur AB (2014, Appendix 8)

Table C.2.

Quality value calculations for the 'old growth forest rich in broad leaves' habitat type in preimpact Mertainen.

\begin{tabular}{|c|c|c|c|c|c|}
\hline $\begin{array}{l}\text { Ecological } \\
\text { attributes }\end{array}$ & $\begin{array}{l}\text { Predefined } \\
\text { weighting of } \\
\text { attributes, A } \\
\text { (\%) }\end{array}$ & $\begin{array}{l}\text { Class } 1 \text {, Score of } \\
\text { impact site in } \\
\text { relation } \\
\text { benchmark } \\
\text { site, } \text { B }^{1}(\%)\end{array}$ & $\begin{array}{l}\text { Class } 2 \text {, Score of } \\
\text { impact site in } \\
\text { relation to } \\
\text { benchmark } \\
\text { site, } B^{2}(\%)\end{array}$ & $\begin{array}{l}\text { Class } 1 \\
\text { Quality } \\
\text { value } \\
(\%)=\text { A X } \\
\text { B }^{1} \\
\end{array}$ & $\begin{array}{l}\text { Class } 2 \\
\text { Quality } \\
\text { value } \\
(\%)=\text { A X } \\
\text { B }^{2}\end{array}$ \\
\hline $\begin{array}{l}\text { Quantity of } \\
\text { biodiversity } \\
\text { trees (no/ha) }\end{array}$ & 25 & 67 & 40 & 17 & 10 \\
\hline Dead wood & 40 & 68 & 27 & 27 & 11 \\
\hline Continuity & 25 & 75 & 50 & 19 & 13 \\
\hline $\begin{array}{l}\text { Wood- } \\
\text { decaying } \\
\text { fungi }\end{array}$ & 5 & 50 & 25 & 3 & 1 \\
\hline Tree lichens & 5 & 100 & 25 & 5 & 1 \\
\hline \multicolumn{2}{|c|}{$\begin{array}{l}\text { Sum of predefined weighting = } \\
100 \%\end{array}$} & \multicolumn{2}{|c|}{ Final aggregated quality value score } & $70 \%$ & $36 \%$ \\
\hline
\end{tabular}

Source: Enetjärn Natur AB (2014, Appendix 8)

Table C.3. 
Ecological Loss-Gain Calculations for Mertainen in Hha.

\begin{tabular}{|c|c|c|c|c|c|}
\hline \multirow[t]{2}{*}{ Habitat type } & \multirow{2}{*}{$\begin{array}{l}\text { Mertainen } \\
\text { Impact area } \\
\text { (Hha) }\end{array}$} & \multicolumn{3}{|c|}{$\begin{array}{l}\text { Kuosajänkkä Compensation area } \\
\text { (Hha) }\end{array}$} & \multirow{2}{*}{$\begin{array}{l}\text { Net compensation = } \\
\text { Kuosajänkkä - } \\
\text { Mertainen (Hha) }\end{array}$} \\
\hline & & $\begin{array}{l}\text { From active } \\
\text { restoration }\end{array}$ & $\begin{array}{l}\text { From } \\
\text { protection }\end{array}$ & Total & \\
\hline $\begin{array}{l}\text { Old growth } \\
\text { forest rich in } \\
\text { broad leaves }\end{array}$ & 32 & 40 & 236 & 276 & +244 \\
\hline $\begin{array}{l}\text { Old growth } \\
\text { coniferous } \\
\text { forest }\end{array}$ & 272 & 16 & 188 & 204 & -68 \\
\hline $\begin{array}{l}\text { Forest- } \\
\text { wetland } \\
\text { mosaic }\end{array}$ & 31 & 0 & 0 & 0 & -31 \\
\hline Wetlands & 115 & 8 & 0 & 8 & -107 \\
\hline Total & 450 & 64 & 424 & 488 & +38 \\
\hline
\end{tabular}

Source: Enetjärn Natur AB (2015)

Table C.4.

Calculations for compensation value in Kuosajänkkä.

\begin{tabular}{|l|l|l|l|l|l|l|l|}
\hline Habitat & $\begin{array}{l}\text { Are } \\
\text { a } \\
\text { (ha) }\end{array}$ & $\begin{array}{l}\text { Qualit } \\
\text { yat } \\
\text { year } \\
\text { 0 }\end{array}$ & $\begin{array}{l}\text { Quality } \\
\text { without } \\
\text { protectio } \\
\text { n, year } \\
\mathbf{5 0}\end{array}$ & $\begin{array}{l}\text { Quality } \\
\text { with } \\
\text { protectio } \\
\text { n, year } \\
\mathbf{5 0}\end{array}$ & $\begin{array}{l}\text { Differen } \\
\text { ce in } \\
\text { quality } \\
\text { with and } \\
\text { without } \\
\text { protecti } \\
\text { on }\end{array}$ & $\begin{array}{l}\text { Probabili } \\
\text { ty of } \\
\text { success }\end{array}$ & $\begin{array}{l}\text { Compensati } \\
\text { on value } \\
\text { (Area x } \\
\text { quality } \\
\text { difference x } \\
\text { probability } \\
\text { year 50 }\end{array}$ \\
\hline $\begin{array}{l}\text { Old growth } \\
\text { forest rich in } \\
\text { broad } \\
\text { leaves, Class } \\
1\end{array}$ & 328 & 1.2 & 0.3 & 1.2 & 0.9 & $70 \%$ & 207 \\
\hline $\begin{array}{l}\text { Old growth } \\
\text { forest rich in } \\
\text { broad } \\
\text { leaves, Class } \\
2\end{array}$ & 122 & 0.6 & 0.3 & 0.6 & 0.3 & $80 \%$ & 29 \\
\hline $\begin{array}{l}\text { Old growth } \\
\text { coniferous } \\
\text { forest, Class } \\
1\end{array}$ & 153 & 1.3 & 0.3 & 1.3 & 1.0 & $70 \%$ & 107 \\
\hline $\begin{array}{l}\text { Old growth } \\
\text { coniferous } \\
\text { forest, Class } \\
2\end{array}$ & 202 & 0.8 & 0.3 & 0.8 & 0.5 & $80 \%$ & 81 \\
\hline $\begin{array}{l}\text { Forest- } \\
\text { wetland } \\
\text { mosaic }\end{array}$ & 0 & - & - & - & 0.4 & 0 & 0 \\
\hline $\begin{array}{l}\text { Wetlands, } \\
\text { Class 1 }\end{array}$ & 870 & 0.6 & 0.6 & 0.6 & 0 & - & \\
\hline $\begin{array}{l}\text { Wetlands, } \\
\text { Class 2 }\end{array}$ & 69 & 0.4 & 0.4 & & & & \\
\hline
\end{tabular}




\begin{tabular}{|l|l|l|l|}
\hline $\begin{array}{l}\text { Sum of } \\
\text { compensati } \\
\text { on area } \\
\text { (ha) }\end{array}$ & $\begin{array}{l}174 \\
4\end{array}$ & $\begin{array}{l}\text { Sum of compensation value through area protection } \\
\text { (Hha) }\end{array}$ & 424 \\
\hline
\end{tabular}

Source: Enetjärn Natur AB (2015, p. 9)

\footnotetext{
Notes

${ }^{\mathrm{i}}$ See CBD-COP12 Decision XII/3.

ii The County Administrative Board is an administrative authority that coordinates State activities in the county.

iii There are three types of courts under the Swedish judicial system (General courts, Administrative courts and Special courts). District courts fall under the category of general courts, while five district courts in Sweden have Land and Environmental Courts.

iv See https://www.notisum.se/rnp/sls/lag/19980808.HTM

${ }^{v}$ See Prop. 1997/98:45 http://www.regeringen.se/sb/d/108/a/1352

${ }^{v i}$ See Väglag (1971:948) §18 for highways, https://www.notisum.se/rnp/sls/lag/19710948.htm, Lag (1995:1649) $\S 15$ for railways, https://www.notisum.se/rnp/sls/lag/19951649.htm and Plan- och bygglag (2010:900) for housing developments https://www.riksdagen.se/sv/Dokument-Lagar/Lagar/Svenskforfattningssamling/Plan-och-bygglag-2010900 sfs-2010-900/

vii The 13th Conference of the Parties was attended by over 7,000 participants including 4,000 delegates from 170 countries and over 400 organizations (See https://www.cbd.int/conferences/2016).

viii See http://umea.naturskyddsforeningen.se/2015/06/30/yttrande-vastra-lanken/; http://www.umea.se/umeakommun/trafikochinfrastruktur/trafikochgator/gator/gatuarbeten/umeaprojektete4e12. 4.bbd1b101a585d7048000168124.html and http://www.trafikverket.se/umeaprojektet

ix A representative of the Västerbotten $\mathrm{CAB}$ noted "The development first needs to acquire permission for the project. If the $\mathrm{CAB}$ refuses permission, it would not matter even if there were a compensation plan proposal. A license-to-trash cannot be bought by developers who offer to conduct compensation". A representative of Norrbotten CAB emphasised, "You cannot pay your way out of inflicting damage on a national interest". Lastly, a representative of the Land and Environmental Court stated, "Even if there would be no compensation, the mining development would still be permitted".

${ }^{x}$ Decision XIII/20 of the 2016 Conference of the Parties on Resource mobilization states: "26. Requests the Executive Secretary to compile and analyse information, including good practices or lessons learned, on how, in accordance with paragraph 16 in Decision XII/3, Parties, other Governments, international organizations, business organizations and other stakeholders take the voluntary guidelines on safeguards in biodiversity financing mechanisms into account when selecting, designing and implementing biodiversity financing mechanisms, and when developing instrument-specific safeguards for them".

xi See International Covenant on Civil and Political Rights (adopted 16 December 1966, entered into force 23 March 1976) 999 UNTS 171.
} 